UCRL-ID-124914

\title{
National Ignition Facility Site Requirements
}

National Ignition Facility Project

RECEIVED

SEP 201996

OSTI

July 1995
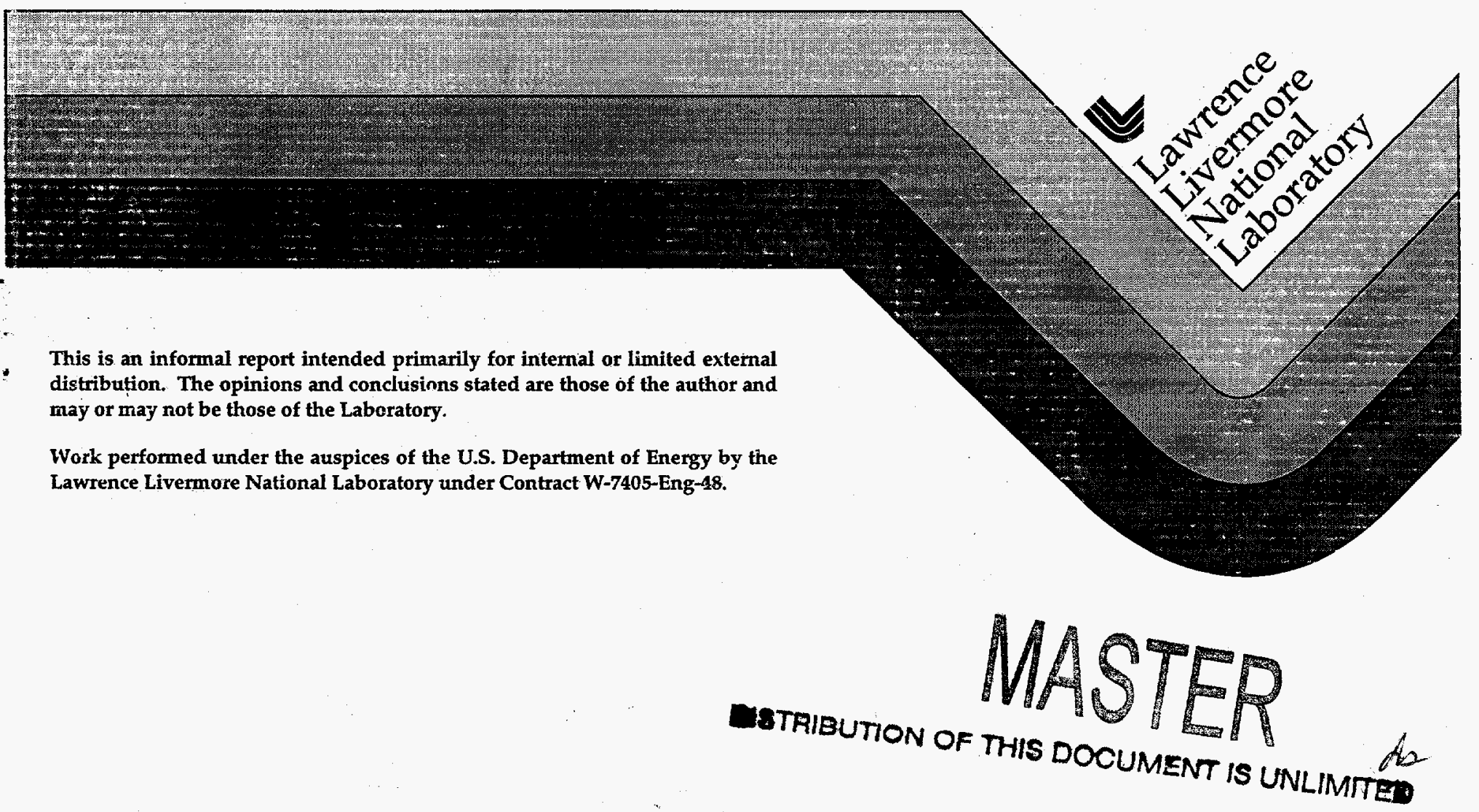


\section{DISCLAIMER}

This document was prepared as an account of work sponsored by an agency of the United States Government. Neither the United States Government nor the University of California nor any of their employees, makes any warranty, express or implied, or assumes any legal liability or responsibility for the accuracy, completeness, or usefulness of any information, apparatus, product, or process disclosed, or represents that its use would not infringe privately owned rights. Reference herein to any specific commercial product, process, or service by trade name, trademark, manufacturer, or otherwise, does not necessarily constitute or imply its endorsement, recommendation, or favoring by the United States Government or the University of California. The views and opinions of authors expressed herein do not necessarily state or reflect those of the United States Government or the University of California, and shall not be used for advertising or product endorsement purposes.

This report has been reproduced directly from the best available copy.

Available to DOE and DOE contractors from the

Office of Scientific and Technical Information

P.O. Box 62, Oak Ridge, TN 37831

Prices available from (615) 576-8401, FTS 626-8401

Available to the public from the National Technical Information Service

U.S. Department of Commerce 5285 Port Royal Rd., Springfield, VA 22161 


\section{DISCLAIMER}

Portions of this document may be illegible in electronic image products. Images are produced from the best available original document. 


\section{Table of Contents}

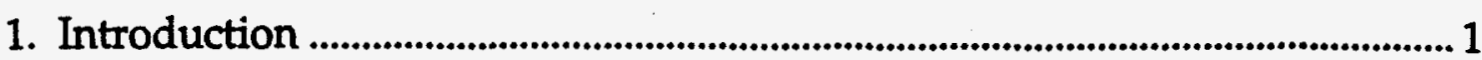

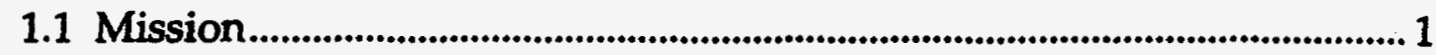

1.2 Site Requirements Purpose and Scope ........................................................ 1

1.2.1 Purpose ........................................................................................................

2. Physical Description ..................................................................................................... 2

2.1 Physical Description of the NIF ....................................................................2 2

2.1.1 Baseline and enhanced envelope ............................................................. 2

2.1.2 Physical decription ....................................................................................... 2

2.1.3 Consistent nomenclature ........................................................................... 3

2.2 NIF Site Requirements......................................................................................... 4

2.2.1 Site Physical Characteristics ..........................................................................5

2.2.2 Environmentally Sensitive Areas.................................................................5

2.2.3 Site Roads and Parking Areas .....................................................................6

2.2.4 Transportation Network .......................................................................... 7

2.2.5 Site Utilities ............................................................................................................. 7

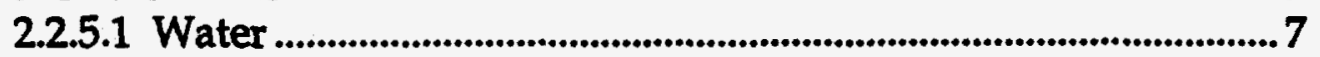

2.2.5.2 Energy Use ...........................................................................................

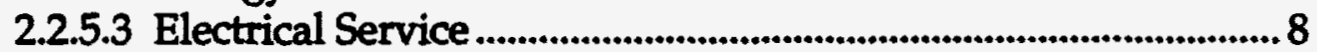

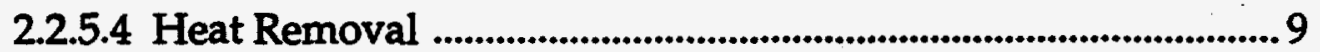

2.2.6 NIF Security .......................................................................................9

2.2.7 NIF Recovery Requirements.............................................................. 10

2.3 Buildings and Special Equipment....................................................................11

2.3.1 NIF Laser and Target Area Building .................................................... 11

2.3.1.1 Laser and Target Area Building Design Requirements ............ 12

2.3.2 NIF Support Capabilities ..................................................................... 13

2.3.2.1 Office Space .....................................................................................13

2.3.2.2 Target Receiving, Inspection, Storage and Repair.......................14

2.3.2.3 Assembly Area - Clean Room/Optics Fabrication ..................... 14

2.3.2.4 Assembly Area-General............................................................... 18

2.3.2.5 Optics Maintenance and Refurbishing Area ................................ 18

2.3.2.6 Optics Storage ..................................................................................... 18

2.3.2.7 Warehouse............................................................................ 18

2.3.2.8 Electrical and Mechanical Shop Capability ................................ 18

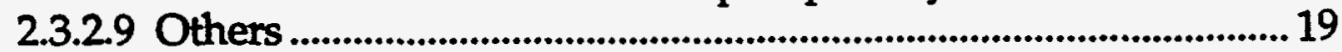

2.4 Site Environmental Considerations ............................................................... 19

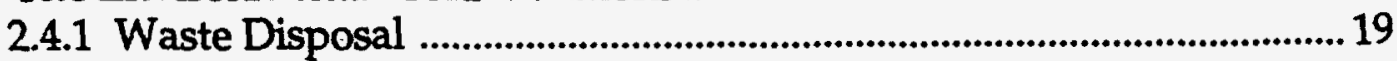

2.4.1.1 Nonhazardous Liquid Waste ..................................................... 19

2.4.1.2 Nonhazardous Solid Waste .......................................................... 20

2.4.1.3 Radioactive, Hazardous, and Mixed Waste Generation .......... 20

2.4.1.4 Hazardous Waste Management ................................................... 20

2.4.2 NIF Radiation Source Terms ......................................................... 21

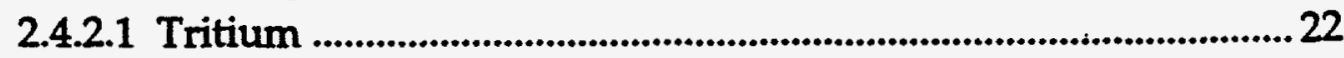

2.4.2.2 Direct Radiation and Skyshine .................................................. 22 


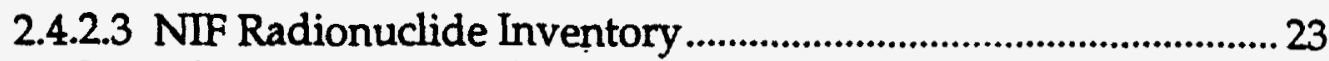

2.4.3 Nonradioactive Atmospheric Emissions ............................................. 24

2.4.4 Nonradioactive Hazardous Chemical Inventory ................................24

2.5 NIF Operational Personnel ..................................................................... 28

2.5.1 NIF Operational Philosophy .................................................................. 28

2.5.2 Engineering, Operations, and Maintenance Support Personnel ..... 28

2.5.3 Scientific Personnel ..................................................................................32

2.6 Support Equipment..............................................................................................33

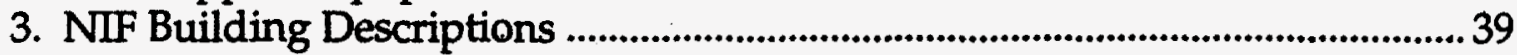

3.1 Laser and Target Area Building - Laser Bays .................................................39

3.2 Laser and Target Area Building-Target Area ................................................4 41

3.3 Office Space .....................................................................................................42

3.4 Target Receiving and Inspection...................................................................... 43

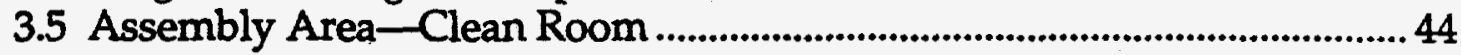

3.6 Assembly Area-General..............................................................................45

3.7 Optics Maintenance and Refurbishing Area ..................................................4 46

3.8 Optics Storage .................................................................................................... 47

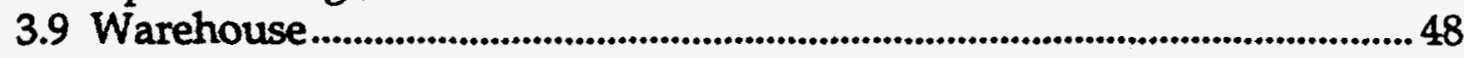

3.10 Electrical and Mechanical Shops ......................................................................49

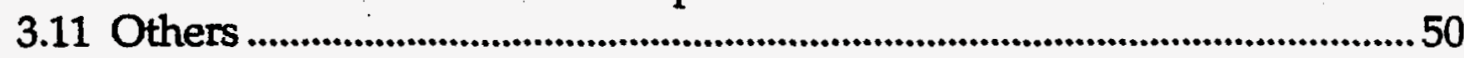

3.11.1 Shipping Receiving, and Central Stores ............................................50

3.11.2 Medical Building ........................................................................................5

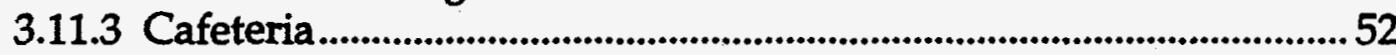

3.11.4 Garage and Gas Station ....................................................................53

3.11.5 Fire Station ........................................................................................... 54

3.11.6 Security and Badging.............................................................................. 55 


\section{List of Figures}

Figure 2-1. Conceptual site plan for NIF and support buildings 15

Figure 2-2. Elevation and plan view of the NIF Laser and Target Area

Building 16

Figure 2-3. Overall view LTAB showing special equipment

\section{List of Tables}

Table 2-1. Annual energy use requirements. 8

Table 2-2. NIF system recovery requirements. 10

Table 2-3. Hazardous and radioactive waste generation.

Table 2-4. Assumptions used for air activation and shielding calculations. ...... 21

Table 2-5. Radionuclides production and stack emissions for the NIF target room. 22

Table 2-7. NIF estimated maximum radionuclide inventory. .23

Table 2-8. Nonradioactive atmospheric emissions. .24

Table 2-9a. NIF Baseline estimated chemical inventories. 25

Table 2-9b. NIF Enhanced Envelope estimated chemical inventories.

Table 2-16. NIF engineering, operations, and maintenance support. 30

Table 2-17. NIF scientific support. 32

Table 2-18. NIF support equipment. 


\section{Introduction}

\subsection{Mission}

The National Ignition Facility (NIF), proposed by the Office of Inertial Confinement Fusion (ICF), will be a key element in the Defense Programs aboveground experimental (AGEX) capabilities for maintaining nuclear competence and weapons effects simulation. The primary mission of the NIF. Project will be to demonstrate fusion ignition in the laboratory. The most immediate application of the NIF will be to provide nuclearweapon-related physics data, since many phenomena occurring on the laboratory scale are similar and relevant to those occurring in weapons. The NIF may also provide an important capability for weapons effects simulation. The second purpose for the NIF is to achieve propagating fusion burn and modest energy gain for development as a source of civilian energy, as stated in the NIF Justification of Mission Need which was endorsed by the Secretary of Energy, the DOE's Fusion Policy Advisory Committee, and the National Academy of Sciences Inertial Fusion Review Group.

\subsection{Site Requirements Purpose and Scope}

\subsubsection{Purpose}

The Site Requirements (SR) provide bases for identification of candidate host sites for the NIF and for the generation of data regarding potential actual locations for the facilities. The SR supplements the NIF Functional Requirements (FR) with information needed for preparation of responses to queries for input to a HQ DOE site evaluation. The queries are to include both documents and explicit requirements for the potential host site responses.

The SR include information extracted from the NIF FR (for convenience), data based on design approaches, and needs for physical and organization infrastructure for a fully operational NIF.

The FR and SR describe requirements that may require new construction or may be met by use or modification of existing facilities.

The SR do not establish requirements for NIF design or construction project planning. The SR document does not constitute an element of the NIF technical baseline. 


\section{Physical Description}

\subsection{Physical Description of the NIF}

This section provides a description of the baseline and enhanced envelope physical description and consistent nomenclature.

\subsubsection{Baseline and enhanced envelope}

The baseline definition of the NIF is contained in the National Ignition Facility Conceptual Design Report (CDR), UCRL-PROP-117093, NIF-LLNL94-113, L-16973-1, May 1994. The baseline from the aspect of site impact can be characterized as:

- Maximum design yield

- Annual total yield

- Tritium throughput

- Tritium inventory (maximum)
$20 \mathrm{MJ}$

$385 \mathrm{MJ}$

$600 \mathrm{Ci} / \mathrm{y}$

$300 \mathrm{Ci}$

All of the effluent, waste, radiological levels derive from the basic criteria and from the NIF design features.

After the CDR was completed, DOE requested a study be performed to evaluate the facility modifications necessary to conduct direct drive in addition to the indirect drive experiments, also Users have identified testing needs which would result in a larger number of yield experiments. An enhanced envelope has been defined for use in the PEIS to cover the impacts of adding: 1) direct drive experiments; 2) enhanced indirect drive for weapons physics, energy and science; and 3) capabristy to perform an increased number of experiments per year to accomodate increased User needs. The enhanced envelope is defined as:

- Maximum design yield

- Annual total yield

- Tritium throughput

- Tritium inventory (maximum)
$20 \mathrm{MJ}$ (with a $45 \mathrm{MJ}$ maximum credible yield used for $1200 \mathrm{MJ}$ $1750 \mathrm{Ci} / \mathrm{y}$ $500 \mathrm{Ci}$

\subsubsection{Physical decription}

The NIF Laser and Target Area Building (LTAB) will house a multi-beamline, Nd glass laser system and target systems capable of performing igntion fusion experiments. The laser system is designed to provide a laser output pulse energy of $1.8 \mathrm{MJ}$ and an output pulse power of $500 \mathrm{TW}$ for pulses at a wavelength of $0.35 \mu \mathrm{m}$. In the target chamber, a positioner will center a target containing fusion fuel, a deuterium-tritium mixture, for each ignition shot. 
Diagnostics in the chamber provide the test data (e.g., neutron and $x$-ray yields).

The building housing the LTAB is required to provide an optically stable and clean environment. The building is required to provide shielding and confinement systems for radiation protection and will be designed as a lowhazard, nonnuclear building capable of withstanding the natural phenomena specified for the selected site. The baseline building design shall not preclude future upgrade for weapons physics experiments, and direct-drive and/or weapon effects target chambers which are not within the NIF Project scope.

The changes to accomodate the enhanced envelope are modest. They include changes in test chamber openings, optics systems, target storage, target positioner and shroud, and decontamination system. The construction impacts (e.g., effluents, etc.) would be unchanged except for a modest increase in materials of construction. Operational impacts are shown in the next sections.

The NIF requires a significant infrastructure to be able to meet its goals. This includes a resource of scientific, engineering, and operations personnel experienced in Inertial Confinement Fusion (ICF) and large laser system operation and maintenance. The on-site support facilities required include: offices for on-site and off-site technical personnel, laser and optics support laboratories, target receiving, inspection, storage and repair, component and system assembly, storage, site emergency services (e.g., fire department, medical, etc.), safeguards and security systems, classified and unclassified computer systems, library, cafeteria, etc. In addition, the host site must be able to manage hazardous and radioactive wastes. The off-site support required includes target fabrication and fill, high technology manufacturing, general construction, machine shop, and assembly support.

\subsubsection{Consistent nomenclature}

To provide consistent information for the candidate host sites, throughout this document the National Ignition Facility (NIF) is described in the following breakdown:

National Ignition Facility

- NiF Building Complex

- Laser and Target Area Building (LTAB)

- Support buildings

- NIF equipment

- Special equipment (e.g., lasers, target chambers, etc.)

- Support equipment 
- NIF site

- Area within the host-site where the NIF building complex is located.

Further, throughout this document, the terms "shall" and "should" are used according to the definitions contained in DOE 6430.1A:

- Shall - denotes a requirement

- Should - denotes a recommendation

\subsection{NIF Site Requirements}

The NIF will require specially designed and constructed buildings to meet the specific requirements for the operation of the laser and experimental area. All structures constructed within the NIF site shall be designed in accordance with all applicable DOE Orders as of the start of Title I design. When DOE Orders are cited in this document, they are meant to be for reference and may not be all inclusive. Orders not part of the DOE contract for the operator of a particular host site for the NIF will require review.

Where existing buildings are proposed for the NIF complex, the application of DOE Orders shall be considered on a graded basis, consistent with the applicable DOE policies on retrofit:

- Building shielding and radioactive confinement systems shall meet the applicable DOE Orders for newly constructed systems without exception.

- The LTAB shall meet all applicable DOE Orders for natural phenomena requirements for important buildings; for resistance to seismic and wind forces the LTAB shall meet the requirements for a critical building.

- Fire protection shall ensure Maximum Possible Fire Loss (MPFL) is limited to $\$ 150 \mathrm{M}$.

- The LTAB Electrical systems shall be designed and constructed to meet the requirements for IEEE 493, Recommended Practice for Design of Reliable Industrial and Commercial Power Systems, ANSI C2, National Electrical Safety Code; NFPA 70, National Fire Protection Association. In accordance to DOE Order 6430.1A the electrical systems shall be designed for non-critical loads. 
- Security systems shall be upgraded to meet application of DOE Orders on physical protection of classified equipment, information, and DOE property.

- Standard support buildings (e.g., warehouses, machine shops, cafeterias, etc.) shall be reviewed from the standpoint of life safety and security. If upgrades are required to meet applicable DOE Safety and Security requirements, they shall meet the requirements of these Orders.

The specific details of the LTAB and support complex will be developed in the NIF CDR that is being prepared. However, the general characteristics and initial functional requirements of the NIF conventional buildings are summarized in this document. In addition, site improvements, utilities, and equipment are identified as being required to meet the overall operational needs.

This document assumes that the required access roads and utility services such as water, sewer, natural gas or alternate heating fuel, electrical power, and communication tie-ins can be provided at each candidate host site. Therefore, these additional utilities and support services have not been specified.

\subsubsection{Site Physical Characteristics}

The NIF is projected to require approximately $0.20 \mathrm{~km}^{2}$ for all operational spaces required to perform the necessary functions of the NIF. A preliminary site layout is presented in Figure 2-1. Some of these operational spaces may currently exist at the host site and could be shared, which would reduce the size of the NIF complex. The minimum dimension of the NIF site will be determined by a site layout evaluation and the selected site should be suitable for construction (e.g., not requiring significant earthwork and including room for construction laydown area, etc.)

\section{Flood Areas}

The NIF LTAB shall be located at a site above or otherwise protected from flood levels that meets or exceeds the criteria for the "low hazard" category defined in DOE STD 1020-94, including the event combinations shown in Table 6-2 of that document.

Soil Instability

The NIF experimental buildings should not be located in an area that is affected by extensive ground failure caused by surface faulting, liquefaction, and other soil instability factors.

\subsubsection{Environmentally Sensitive Areas}

The siting of the NIF must consider the impact of construction and operation on surrounding ecosystems and other environmentally sensitive areas. DOE Order 4300.1B provides the basic guidance for consideration of these issues. The requirements are listed below. 
Wetlands Location

The NIF shall avoid development, modification, or occupancy of flood plains and wetlands where practical alternatives exist (per Executive Orders 11988 and 11990).

\section{Endangered Species}

The construction and operation of the NIF shall not adversely impact threatened, endangered, other species of concern, or their habitats per the Endangered Species Act of 1973, as amended and applicable State Endangered Species Acts.

The identification of threatened, endangered, and other species of concern is based on both federal government and host site's state government lists, in consultation with the U.S. Fish and Wildlife Service and the responsible state agency.

\section{Wildlife Communities}

A site-specific survey and evaluation of the impact of the construction and operation of the NIF on the wildlife habitats shall be conducted.

\section{Native American Religious Sites}

Native American groups shall be consulted to avoid undue impact as a result of building the NIF on a traditional or cultural place, per the American Indian Religious Freedom Act.

\section{Historic and Cultural Resources Sites}

All interested parities shall be consulted concerning the impact as a result of building the NIF on a historic and/or cultural resources site, as defined by the Archeological and Historic Preservation Act of 1974.

\section{Pre-existing Condition: Contaminated Soil}

The NIF site should not have a pre-existing condition of contaminated soil requiring significant environmental remediation. For example, the soil should not have been contaminated with materials such as gasoline, chromium, specific volatile organic or radioactive materials.

\subsubsection{Site Roads and Parking Areas}

Site roads and parking areas will be required to accommodate transportation in support of the NIF. The maximum number of personnel.on site during normal operating conditions is estimated to be 600 people per day which includes: (1) a permanent operating/scientific staff of approximately 300 , (2) up to 260 visiting scientists and 1200 other site visitors per year. It is estimated that there will be 1200 routine truck shipments per year and 335 tritium-containing target shipments per year (the total number of target shipments will be greater). During operation, the largest trucks expected would be of the type used to 
deliver liquid nitrogen to the LTAB and other assembly areas.

2.2.4 Transportation Network

There should be a sufficient transportation network to deliver cryogenic targets from the fabrication facilities to the LTAB. It is estimated that these targets shall be delivered to the NIF within 24 hours of the departure from the fabrication facilities within the continental U.S.

\subsubsection{Site Utilities}

The utilities addressed in this section include water, fuel, electricity and heat removal.

2.2.5.1 Water

Water will be required for cooling, sanitary (potable) needs, and fire protection.

Water supply lines

Water supply shall be capable of meeting the full raw water needs of the NIF, which are estimated at approximately 152 million liters/yr.

Sanitary Water Quantity

The quantity of sanitary (potable) water available to the NIF should be $49,160 \mathrm{l} /$ day al $413.7 \mathrm{KPa}$ at $413 \mathrm{KPa}$, with a peak flow capacity of $9461 / \mathrm{min}$.

\section{Fire Protection Water}

The fire protection water requirements in accordance with DOE $5480.7 \mathrm{~A}$ are as follows: (1) the quantity of water available for fire protection of the NIF is $75701 / \mathrm{min}$; (2) at this delivery rate, water pressure in the hydrants shall not drop below $137.9 \mathrm{KPa}$; and (3) at this flow rate and pressure, the water flow shall be able to be maintained for a minimum of 2 hours and include a redundant fire protection system.

\subsubsection{Energy Use}

Electrical power and fuel shall be provided to the NIF site for operation of the experiments, equipment, facilities and for standby electrical generation, as described. The heating and air conditioning requirements have been based on the following. 


\begin{tabular}{lcc}
\hline & Summer & Winter \\
\hline \hline Outside design conditions & $37.8^{\circ} \mathrm{C}$ (Design basis) & \\
& $20.6^{\circ} \mathrm{C}$ (Wind basis) & $-4.4^{\circ} \mathrm{C}$ (Design basis) \\
Inside design temperature & & \\
Laser bay and target area & $20^{\circ} \mathrm{C} \pm 0.28^{\circ} \mathrm{C}$ & $20^{\circ} \mathrm{C} \pm 0.28^{\circ} \mathrm{C}$ \\
Clean rooms & $20^{\circ} \mathrm{C} \pm 0.28^{\circ} \mathrm{C}$ & $20^{\circ} \mathrm{C} \pm 0.28^{\circ} \mathrm{C}$ \\
Office areas & $25.6^{\circ} \mathrm{C} \pm 1.1^{\circ} \mathrm{C}$ & $22.2^{\circ} \mathrm{C} \pm 1.1^{\circ} \mathrm{C}$ \\
\hline
\end{tabular}

Natural gas was assumed as the heating fuel. Table 2-1 presents the annual energy use requirements.

Table 2-1. Annual energy use requirements.

\begin{tabular}{|c|c|c|c|}
\hline Area & Source & Quantity & Use \\
\hline \multirow{2}{*}{$\begin{array}{l}\text { NIF Laser and } \\
\text { Target Area } \\
\text { Building }\end{array}$} & Natural Gas & $21,075,000 \mathrm{MJ} / \mathrm{Yr}$ & HVAC \\
\hline & Diesel Fuel & $\begin{array}{l}311,000 \mathrm{MJ} / \mathrm{Yr} \\
21,400,000 \mathrm{MJ} / \mathrm{Yr} \\
17,280 \mathrm{Mw}-\mathrm{h} / \mathrm{Yr}_{\mathrm{r}} \\
8,160 \mathrm{Mw}-\mathrm{h} / \mathrm{Yr} \\
2,600 \mathrm{Mw}-\mathrm{h} / \mathrm{Yr}_{\mathrm{r}} \\
28,040 \mathrm{Mw}-\mathrm{h} / \mathrm{Yr}_{\mathrm{r}} \\
320 \mathrm{~L} / \mathrm{Yr}\end{array}$ & $\begin{array}{l}\text { Domestic Hot Water } \\
\text { TOTAL } \\
\text { HVAC } \\
\text { Lights } \\
\text { Other } \\
\text { TOTAL } \\
\text { Stand-By Power }\end{array}$ \\
\hline \multirow{2}{*}{$\begin{array}{l}\text { NIF Support } \\
\text { Facilities }\end{array}$} & Natural Gas & $19,500,000 \mathrm{MJ} / \mathrm{Yr}$ & Heating and Hot Water \\
\hline & Electricity & $30,000 \mathrm{Mw}-\mathrm{h} / \mathrm{Yr}$ & $\begin{array}{l}\text { Building and Laboratory } \\
\text { Use Including HVAC } \\
\text { and Lights } \\
\text { Stand-By Power }\end{array}$ \\
\hline
\end{tabular}

\subsubsection{Electrical Service}

A 25MVA electrical power distribution system with a 18/21/24 MVA transformer capacity electrical substation has been estimated to be required for NIF experimental and support facilities. Electrical power shall be installed in accordance with NFPA 70, the National Electrical Code, IEEE 493, Recommended Practices for Design of Reliable Industrial and Commercial Power Systems, and ANSI C2, the National Electrical Safety Code.

The primary requirement for electrical power is to maintain building 
environmental conditions. However, several important functions require that the utility power supply system have a high degree of both reliability and quality. These functions include the computers for experimentation instruments, control and data acquisition and the target environmental control. Power interruptions of a few minutes in duration when the experimental system is in the ready state, will likely result in the loss of a full working shift in order to reestablish the experimental system to its operating condition. Reliable power delivery will be vital for satisfying the NIF system reliability, availability, and maintainability requirements as stated in the Functional Requirements.

\section{Voltage Quality}

This power supply system voltage shall be maintained in conformance with ANSI C84.1, Electrical Power Systems and Equipment - Voltage Ratings $(60 \mathrm{~Hz})$. Electrical Power Distribution systems shall operate within the limits specified for Range A of this specification. Voltage occurrences outside these limits should not exceed the Range B limits. These variances should be limited in extent, frequency, and duration. When these occur, corrective measures shall be undertaken in Table 1 and Figure B1 of the above standard.

\section{Standby Power}

Standby power shall be part of the NIF project unless the site can provide reliable standby power of approximately $300 \mathrm{KW}$ to LTAB and target receiving and storage area. The time required to transfer power from the stand-by generator should be 8 seconds.

\subsubsection{Heat Removal}

The major source of heat rejection at this site will be from building environmental heat loads.

A system to provide cooling for the LTAB, support facilities and experimental equipment will be required; the estimated heat load is equivalent to $12 \mathrm{MW}$.

\subsubsection{NIF Security}

The NIF will be designed and operated in conformance with the DOE 5632 series of orders, which establishes departmental policies and requirements for the physical protection of DOE property and security interests. Requirements include those for physical protection of classified matter; physical protection of DOE property and unclassified facilities; protective program operations; and personnel security, including issuance, control, and use of badges, passes, and credentials.

The NIF will have limited areas for the handling, protection, and storage of classified material. Automated Data Processing (ADP) systems handling classified information shall meet the requirements of DOE Orders 5637.1 Classified Computer Security Program and 5300.4 B, Telecommunications: 
Protected Distribution System.

Because the continuous operation of the NIF is not required to prevent adverse impacts on national security or the health and safety of the public, it is not classified as a vital building per DOE Order 5632.2A, Physical Protection of Special Nuclear Material and Vital Equipment.

\subsubsection{NIF Recovery Requirements}

The NIF has the following recovery requirements from events ranging from normal to extremely unlikely events. The host sites need to ensure that the selected NIF site is compatible with these requirements (see Table 2-2). For example, for anticipated events such as the 100-y flood, the NIF and its site must support recovery of operation within days without extensive corrective action. Of greater importance from the standpoint of safety, extremely unlikely events may not result in significant adverse impacts to the public or the environment.

Table 2-2. NIF system recovery requirements.

\begin{tabular}{|l|l|l|l|}
\hline $\begin{array}{c}\text { Recovery } \\
\text { Requirements }\end{array}$ & \multicolumn{1}{|c|}{ Description } & $\begin{array}{l}\text { P, Probability of } \\
\text { Occurrence Per } \\
\text { Year }\end{array}$ & Impact/Recovery \\
\hline \hline Rapid recovery & $\begin{array}{l}\text { Interruptions to } \\
\text { normal operations } \\
\text { including random } \\
\text { failures and } \\
\text { wear-out. }\end{array}$ & $\mathrm{P}=1$ & $\begin{array}{l}\text { Continue operation } \\
\text { with minor outages } \\
\text { (e.g., } 24 \text { h) as } \\
\text { required to meet NIF } \\
\text { availability } \\
\text { requirements. }\end{array}$ \\
\hline Normal recovery & $\begin{array}{l}\text { Events that may } \\
\text { occur once or more } \\
\text { during NIF lifetime } \\
\text { (e.g., 100-y flood). }\end{array}$ & $1>\mathrm{P} \geq 10^{-2}$ & $\begin{array}{l}\text { NIF may } \\
\text { experience outage of } \\
\text { days but returns to } \\
\text { operation without } \\
\text { extensive corrective } \\
\text { action (e.g., repair) } \\
\text { as required to meet } \\
\text { NIF availability } \\
\text { requirements. }\end{array}$ \\
\hline Extended recovery & $\begin{array}{l}\text { Events unlikely to } \\
\text { occur during NIF } \\
\text { lifetime. }\end{array}$ & $10^{-2}>\mathrm{P} \geq 5 \times 10^{-4}$ & $\begin{array}{l}\text { NIF down for } \\
\text { perhaps months, } \\
\text { but capable of } \\
\text { returning to } \\
\text { operations after } \\
\text { extensive corrective } \\
\text { action. }\end{array}$ \\
\hline
\end{tabular}


Table 2-2. (cont.) NIF system recovery requirements.

\begin{tabular}{|l|l|l|l|}
\hline Non-recovery & $\begin{array}{l}\text { Severe events not } \\
\text { expected to occur } \\
\text { during NIF lifetime. }\end{array}$ & $5 \times 10^{-4}>\mathrm{P} \geq 10^{-6}$ & $\begin{array}{l}\text { NIF severely } \\
\text { damaged but no } \\
\text { significant adverse } \\
\text { impact to public or } \\
\text { environmental; } \\
\text { event may preclude } \\
\text { further use without } \\
\text { major } \\
\text { reconstruction. }\end{array}$ \\
\hline $\begin{array}{l}\text { Incredible events } \\
\text { (not considered) }\end{array}$ & $\begin{array}{l}\text { Events of extremely } \\
\text { low probability of } \\
\text { occurrence. }\end{array}$ & $\mathrm{P}<10^{-6}$ & $\begin{array}{l}\text { Not considered in } \\
\text { design. }\end{array}$ \\
\hline
\end{tabular}

From the standpoint of recovery requirements, these ranges include the probability of exceedance.

\subsection{Buildings and Special Equipment}

The NIF shall meet the applicable requirements of all DOE Orders and other applicable federal, state, and local building codes.

For the purpose of specifying building requirements, all support buildings are classified as general use as defined in DOE STD 1020-94, and the NIF LTAB and the target receiving and storage buildings are classified as low hazard, nonnuclear.

\subsubsection{NIF Laser and Target Area Building}

The NIF LTAB design will be provided in detail in the NIF CDR. The site requirements document presents preliminary requirements for building size, structure, equipment and environmental conditions. A preliminary building layout for the LTAB is shown in Fig. 2-2. The building layout is generic and the overall experimental systems may be able to be modified to fit into existing buildings. For example, by folding the laser system, the beam path can be reduced by a factor of two.

This building consists of two laser bays, each $130.1 \mathrm{~m}$ long, $24.4 \mathrm{~m}$ wide, and $17 \mathrm{~m}$ high to the bottom of the overhead ceilings, and a target building that is $30.5 \mathrm{~m}$ inside diameter, and $29.3 \mathrm{~m}$ high to the base of the ceiling.

The construction of the laser bays can be pre-engineered metal sandwich, masonry and concrete or concrete exterior walls. The target room will require approximately $1.82 \mathrm{~m}$-thick concrete walls and $1.21 \mathrm{~m}$-thick ceiling for radiation shielding.

The LTAB has been sized to include support areas within this building for 
diagnostics, control room, hazardous waste packaging and labeling, decontamination of equipment, maintenance and target installation. The capacitor banks installation areas are added to the sides of the laser bays. This area is approximately $60.9 \mathrm{~m}$ long, $15 \mathrm{~m}$ wide and $6.1 \mathrm{~m}$ high on each side of the laser bay. The LTAB will have an estimated power requirement of $15 \mathrm{MW}$.

\subsubsection{Laser and Target Area Building Design Requirements}

\section{Structural systems}

The NIF LTAB shall be designed for a 30-yr design life for permanent structures. The resistance of structures, systems, and components to design basis accidents (DBAs) shall be commensurate with their importance to safety. The structural system shall meet the requirements of DOE Order 6430.1A and the performance goals for important or low-hazard buildings in DOE STD 1020-94. With respect to occupant safety and continued operation with minimal interruption, the performance goal annual probability of exceedance is $5 \times 10^{-4}$ for building damage where the building cannot perform its function. The annual probability of exceedance of building damage, as a result of natural phenomena hazards (performance goal), is a combined function of the annual probability of exceedance of the event and factors of safety introduced by the design/evaluation procedures.

\section{Seismic Loads}

The structures and special equipment shall be designed to the seismic provisions of the UBC for Essential Facilities, as modified by the design guidelines in DOE STD 1020-94, and the site-specific seismic parameters summarized in UCRL-53582. (Note: site-specific parameters shall be specified after site selection.)

The following parameters will be used for the conceptual design:

\begin{tabular}{|l|c|}
\hline Horizontal ground acceleration & (Site-specific) $\mathrm{g}$ \\
\hline Importance factor & 1.25 \\
\hline Annual probability of exceedance & $1 \times 10^{-3}$ \\
\hline
\end{tabular}

Wind Loads

The structural frame and building exterior shall be designed to maintain structural integrity and prevent breaching as the result of wind forces acting from any direction. 


\begin{tabular}{|l|c|}
\hline Wind speed & $\begin{array}{c}\text { (Site-specific) mph at } \\
\text { (site-specific) } \mathrm{m} \text { height }\end{array}$ \\
\hline Importance factor & 1.07 \\
\hline Exposure category & $\mathrm{C}$ \\
\hline Annual probability of exceedance & $2 \times 10^{-2}$ \\
\hline
\end{tabular}

\section{Vibration Considerations}

LTAB buildings and areas within support facilities will have vibrationsensitive special equipment. The structural system design shall provide means to effectively isolate this equipment to control vibration within specified displacement and rotation requirements. LTAB laser bay vibration limits must allow the laser system to meet its $50-\mu \mathrm{m}$ rms pointing accuracy requirement.

\section{Ventilation}

Heating, ventilating, and air conditioning (HVAC) systems shall be designed in accordance with DOE Order 6430.1A. A comprehensive building energy and conservation analysis shall be performed to optimize the HVAC systems for minimum energy consumption and minimum building life cycle cost.

The LTAB requires stringent temperature and contamination control. The temperature shall be controlled to $20^{\circ} \mathrm{C} \pm 0.28^{\circ} \mathrm{C}$ by the HVAC system, and the cleanliness of the optical components shall be maintained at the levels achieved during assembly.

\section{Confinement Requirements}

The LTAB HVAC system shall be designed to control airborne radioactive releases to meet the requirements of DOE Order 5400.5 and 40 CFR 61. The target area HVAC system shall be capable of being operated at a negative pressure during and immediately after shots of greater than $1 \mathrm{MJ}$ yield. The final exhaust release point from this system shall be at an elevated point (Note: $26.8 \mathrm{~m}$ used for effluent and safety evaluations.)

\subsubsection{NIF Support Capabilities}

The NIF has requirements for space for a variety of functions to support the operations of the experimental program. These space requirements are discussed in this section. In Section 3.0 there are detailed data sheets describing the specifics of these spaces including height, equipment and environmental requirements, etc. It is not necessary that all these functional areas be located in independent structures. Combining similar functional spaces within a single structure is an acceptable approach to meeting these requirements.

\subsubsection{Office Space}

The office space should accommodate the permanent technical staff and 
visiting scientists. The number of staff personnel and disciplines are identified in Section 2.5. This space can be in a one- or two-story structure with a total floor area estimated at $16,722 \mathrm{~m}^{2}$. This area will provide office space, conference rooms, computer facilities, drafting space, and utilities for telecommunications with other technical facilities.

\subsubsection{Target Receiving, Inspection, Storage and Repair}

This $1393 \mathrm{~m}^{2}$ building will provide laboratories and equipment for receiving and inspecting targets for the NIF. This building consists of several Class 100 clean rooms and inspection laboratories in a vibration-free environment. It also includes cryogenic laboratories and a central chemical waste system. This building must meet the security requirements listed in Section 2.2.6 to handle classified equipment.

\subsubsection{Assembly Area-Clean Room/Optics Fabrication}

The assembly of components for the NIF will require high quality areas to clean, inspect, and assemble the large number of optics and crystals. To perform this activity, a $2413 \mathrm{~m}^{2}$ area consisting of approximately $1022 \mathrm{~m}^{2}$ of clean room space $(60 \%$ Class 100 and $40 \%$ Class 1000$)$ will be required. This clean room area requires a ceiling height of $4.3 \mathrm{~m}$ and will be equipped with a 9.1-ton bridge crane and several smaller hoists. The remaining area will be used for inspection and precleaning. 
Figure 2-1. Conceptual site plan for NIF and support buildings (Dimensions are in $\mathbf{c m}$ )

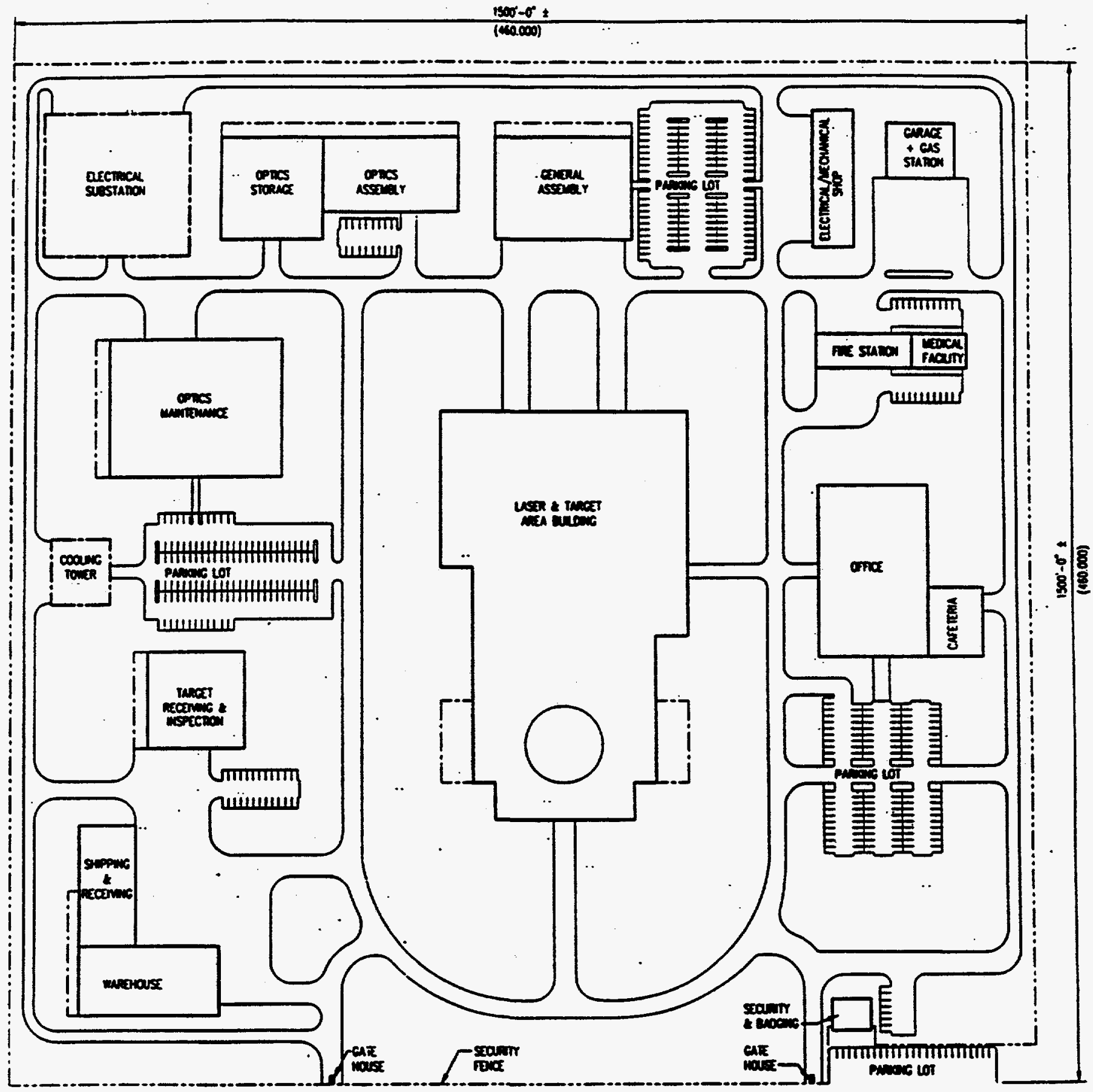


Figure 2-2. Elevation and plan views of the NIF Laser and Target Area Building (Dimensions are in cm)
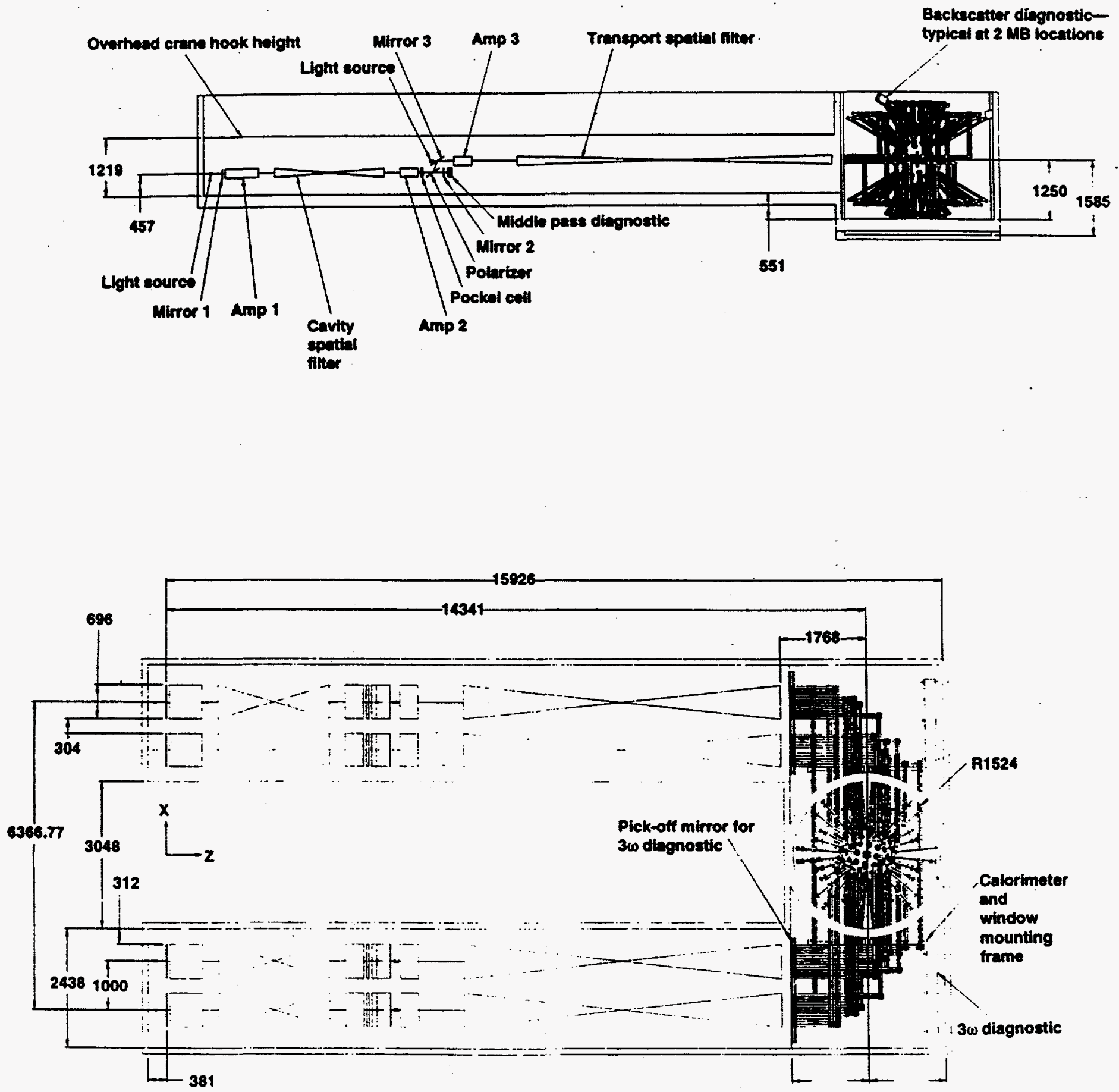
Figure 2-3. Overall view of LTAB showing special equipment

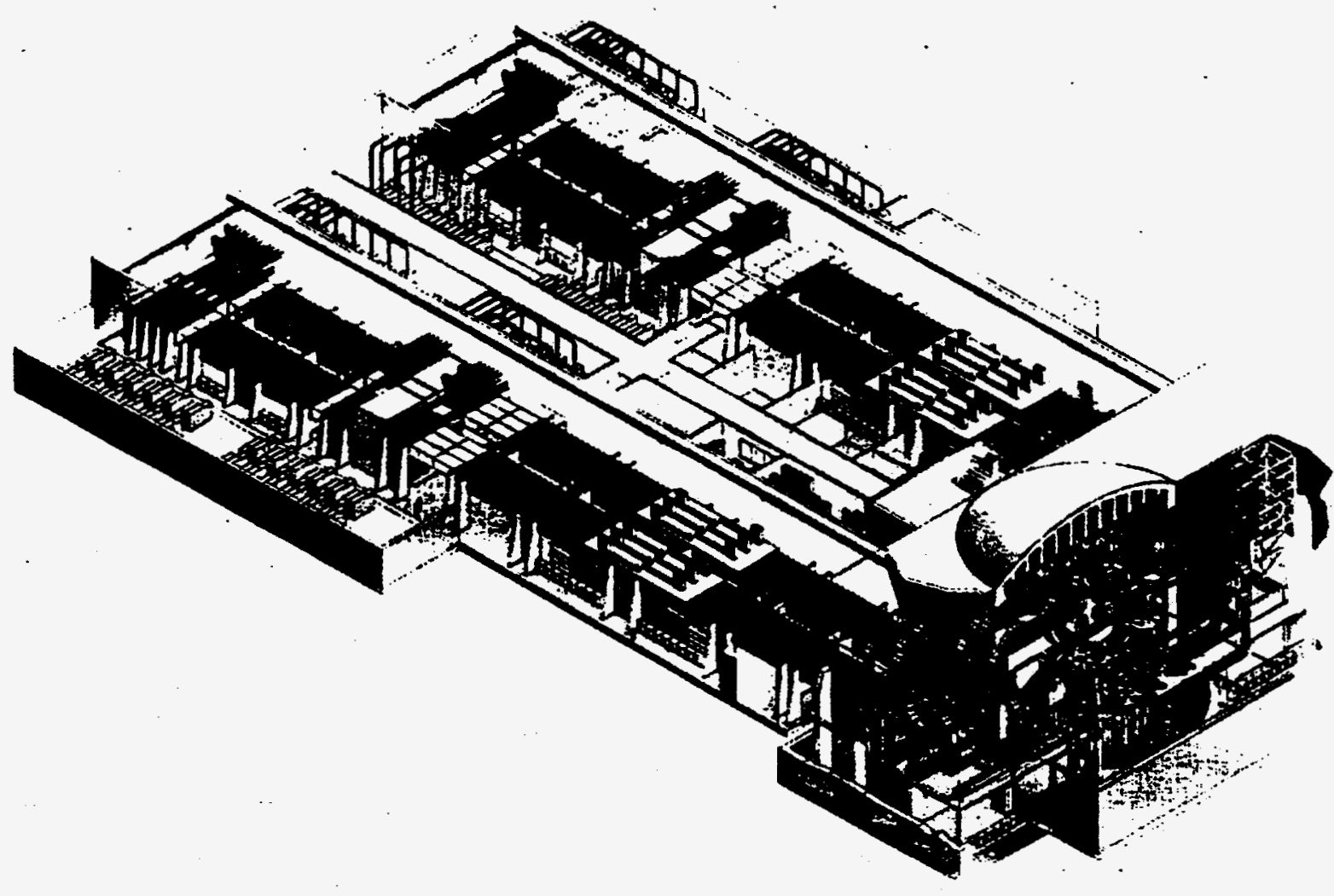




\subsubsection{Assembly Area-General}

This industrial type building of approximately $2787 \mathrm{~m}^{2}$ will be used to assemble mechanical and electrical components that do not require a clean room environment. Large mechanical structures (e.g., spatial filters, mounts) will require special lifting and assembly fixtures and appropriate material handling equipment (e.g., overhead cranes). There must also be provisions for assembly welding. This assembly area can be shared with other operations at the test site.

\subsubsection{Optics Maintenance and Refurbishing Area}

Controlled-environment laboratory space is required for optical fabrication, optical testing, and inspections. This capability can be a part of the host site infrastructure. However, the NIF will require access to this capaiblity to meet operational schedules. The laboratory areas will contain optical coating equipment for refinishing mirror and polarizers, laboratories for resurfacing and cleaning debris shields, and temperature- and humidity-controlled laboratories for optical processing and fabrication of KDP crystals. This building will require vibration isolation, temperature, and humidity controls. Approximately $465 \mathrm{~m}^{2}$ of the total $3716 \mathrm{~m}^{2}$ area will contain Class 100 clean rooms.

\subsubsection{Optics Storage}

This temperature-and humidity-controlled storage and inventory area of approximately $2090 \mathrm{~m}^{2}$ will house the high value optical components (laser disks, mirrors, and KDP crystals) during assembly and spares inventory during operation of the NIF.

\subsubsection{Warehouse}

Approximately $2787 \mathrm{~m}^{2}$ of industrial-quality space will be required for the bulk storage of NIF components, equipment and supplies for operationof the NIF. The warehouse will require minimum utilities.

\subsubsection{Electrical and Mechanical Shop Capability}

This capability will require approximately $1114 \mathrm{~m}^{2}$ to house machine tools for fabricating components and an electrical fabrication and testing area. This area can be a part of the host site infrastructure and need not be dedicated to the NIF. The structure can be an industrial-type, pre-engineered building. 


\subsubsection{Others}

The facilities specified in Section 3.12 include:

- Shipping, receiving and central stores.

- Medical Building.

- Cafeteria.

- Garage and gas station.

- Fire station.

- Security and badging.

Many or all of these services may exist within the host site infrastrucutre and can be used by the NIF. The services shall meet the life safety and security requirement for the NIF per applicable DOE orders. The proximity of these services to the NIF should be considered in order to reduce operational costs.

\subsection{Site Environmental Considerations}

This section will allow each site to evaluate the potential environmental impacts of the normal operation of the NIF in terms of radiation, waste generation, effluents, etc. For example, the radiation source terms to calculate site-boundary dose from direct radiation, skyshine, tritium, and activated air are provided to allow the calculation of site-boundary dose based on the specific location of the NIF (e.g., distance to nearest boundary) and the specific codes and assumptions applicable to that site.

\subsubsection{Waste Disposal}

The NIF site will generate a variety of gaseous, liquid, and solid wastes from the experimental building maintenance, operations, and support buildings.

These wastes are to be handled in accordance with all applicable federal, state, and local regulations for waste management and disposal.

\subsubsection{Nonhazardous Liquid Waste}

The following requirements address the handling of nonhazardous liquid wastes.

Sanitary Wastewater Treatment

A treatment capability shall be provided for the handling of sanitary wastewater, with a capacity of $49,1601 /$ day.

\section{Storm Drain Capacity}

Storm drains shall be available on the NIF site with a capacity adequate for a design basis flood level (DBFL) local rainfall based on a low-hazard-use building per DOE STD 1020-94, Section 6.1.3. The flow from these drains was not included in the sanitary wastewater treatment. 


\subsubsection{Nonhazardous Solid Waste}

Nonhazardous solid waste at the NIF site is estimated to be $6000 \mathrm{~m}^{3} / \mathrm{y}$ per year.

\subsubsection{Radioactive, Hazardous, and Mixed Waste Generation}

Table 2-3 lists the quantities and types of hazardous, low-level radioactive (LLW) and mixed (LLW and hazardous) waste that are expected to be generated at the NIF per year. These waste generation rates are based on the NIF operation and maintenance (e.g., cleaning debris shields) activities.

Table 2-3. Hazardous and radioactive waste generation.

\begin{tabular}{|c|c|c|}
\hline Waste category & $\begin{array}{c}\text { Baseline Case } \\
\text { Annual } \\
\text { generation }\end{array}$ & $\begin{array}{l}\text { Enhanced Envelope } \\
\text { Annual generation }\end{array}$ \\
\hline - Solid: Hazardous* & $3200 \mathrm{~kg} / \mathrm{y}$ & $3200 \mathrm{~kg} / \mathrm{y}$ \\
\hline Low level & $1500 \mathrm{~kg} / \mathrm{y}$ & $1800 \mathrm{~kg} / \mathrm{y}$ \\
\hline Mixed & $140 \mathrm{~kg} / \mathrm{y}$ & $360 \mathrm{~kg} / \mathrm{y}$ \\
\hline - Liquid: Hazardous* & $23001 / y$ & $4600 \mathrm{l} / \mathrm{y}$ \\
\hline Low level & $6001 / y$ & $16001 / y$ \\
\hline Mixed & $20001 / y$ & $50001 / y$ \\
\hline
\end{tabular}

* Solid and liquid hazardous wastes are divided into LTAB and $O A B$ as follows:

Solid hazardous: LTAB (baseline and enhanced) $3000 \mathrm{~kg} / \mathrm{y}$ $\mathrm{OAB}$ (baseline and enhanced) $200 \mathrm{~kg} / \mathrm{y}$

Liquid hazardous: LTAB (baseline and enhanced) $5001 / y$ OAB (baseline) $18001 / y$ $\mathrm{OAB}$ (enhanced) $41001 / \mathrm{y}$

\subsubsection{Hazardous Waste Management}

The NIF shall include the capability to package, characterize and label the hazardous, low-level radioactive and mixed (low-level radioactive and hazardous) wastes generated. This waste shall be treated, stored or disposed of by the host site waste management system. The host site waste management system shall meet all DOE, Federal and state requirements for low level radioactive and hazardous wastes. 


\subsubsection{NIF Radiation Source Terms}

This section includes the data required to calculate the site-boundary radiation intensity from air activation, tritium, and direct and skyshine radiation. The annual yield and NIF physical dimensions are given in Table 2-4.

The neutron-induced radioactivity produced in the target-room air is shown in Table 2-4.

Table 2-4. Assumptions used for air activation and shielding calculations.

\begin{tabular}{|c|c|c|}
\hline & Baseline & $\begin{array}{l}\text { Enhanced } \\
\text { Envelope }\end{array}$ \\
\hline $\begin{array}{l}\text { Annual yield } \\
\text { Leakage into room }\end{array}$ & $\begin{array}{c}1.4 \times 10^{20} \mathrm{D}-\mathrm{T} \text { neutrons } \\
13 \% \text { (chamber openings) } \\
\text { plus scattered }\end{array}$ & $\begin{array}{c}4.4 \times 10^{20} \mathrm{D}-\mathrm{T} \text { neutrons } \\
17 \% \text { (chamber openings) } \\
\text { plus scattered }\end{array}$ \\
\hline $\begin{array}{l}\text { Chamber } \\
\text { Radius (inside) } \\
\text { Thickness } \\
\text { Shield thickness }\end{array}$ & $\begin{array}{c}5.0 \mathrm{~m} \\
0.1 \mathrm{~m} \\
0.4 \mathrm{~m} \text { concrete } \\
\end{array}$ & $\begin{array}{c}5.0 \mathrm{~m} \\
0.1 \mathrm{~m} \\
0.4 \mathrm{~m} \text { concrete } \\
\end{array}$ \\
\hline $\begin{array}{l}\text { Target room } \\
\text { Inside dimensions } \\
\text { (diameter } x \text { height) }\end{array}$ & $30.5 \mathrm{~m} \times 29.3 \mathrm{~m}$ & $30.5 \mathrm{~m} \times 29.3 \mathrm{~m}$ \\
\hline $\begin{array}{l}\text { Cylindrical wall } \\
\text { thickness } \\
\text { Roof thickness }\end{array}$ & $1.82 \mathrm{~m}$ concrete & $1.82 \mathrm{~m}$ concrete \\
\hline
\end{tabular}

Important radionuclide production and stack emissions anticipated for normal NIF operation are shown in Table 2-5. 
Table 2-5. Radionuclides production and elevated release point emissions for the NIF target room.

\begin{tabular}{|c|c|c|c|c|c|}
\hline & & \multicolumn{2}{|c|}{ Baseline } & \multicolumn{2}{|c|}{ Enhanced Envelope } \\
\hline Nuclide & Half-life & $\begin{array}{c}385 \mathrm{MJ} \\
(13 \%) \\
\text { Production } \\
(\mathrm{Ci} / \mathrm{y})\end{array}$ & $\begin{array}{c}\text { Indirect } \\
(13 \%) \\
\text { elevated } \\
\text { emissions } \\
(\mathrm{Ci} / \mathrm{y})\end{array}$ & $\begin{array}{c}1200 \mathrm{MJ} \\
(17 \%) \\
\text { Production } \\
\mathrm{Ci} / \mathrm{y})\end{array}$ & $\begin{array}{c}1200 \mathrm{M}) \\
(17 \%) \\
\text { elevated } \\
\text { emissions } \\
(\mathrm{Ci} / \mathrm{y})\end{array}$ \\
\hline \hline $13 \mathrm{~N}$ & $9.99 \mathrm{~min}$ & 168 & 21 & $6.84 \mathrm{E}+2$ & 86 \\
\hline $16 \mathrm{~N}$ & $7.13 \mathrm{~s}$ & $2.4 \mathrm{E} 4$ & 41 & $9.66 \mathrm{E}+4$ & 166 \\
\hline $37 \mathrm{~S}$ & $5.06 \mathrm{~min}$ & 4.9 & 0.33 & $1.99 \mathrm{E}+1$ & 1.4 \\
\hline $40 \mathrm{Cl}$ & $1.42 \mathrm{~min}$ & 18 & 0.34 & $7.35 \mathrm{E}+1$ & 1.4 \\
\hline $41 \mathrm{Ar}$ & $1.83 \mathrm{~h}$ & 27 & 17 & $8.84 \mathrm{E}+1$ & 54 \\
\hline $14 \mathrm{C}$ & $5730 \mathrm{y}$ & $4.5 \mathrm{E}-4$ & $4.5 \mathrm{E}-4$ & $1.47 \mathrm{E}-3$ & $1.47 \mathrm{E}-3$ \\
\hline $3_{\mathrm{H}}$ & $12.33 \mathrm{y}$ & $1.3 \mathrm{E}-3$ & $1.3 \mathrm{E}-3$ & $5.35 \mathrm{E}-3$ & $5.35 \mathrm{E}-3$ \\
\hline
\end{tabular}

These releases to the environment from air activation result in potential exposures which are well below DOE Order 5400.5 exposure limits (i.e., 10 $\mathrm{mrem} / \mathrm{yr}$. airborne).

\subsubsection{Tritium}

Tritium releases to the environment can also result from the target chamber exhaust. Without any mitigation measures, releases would result in exposures below DOE Order 5400.5 exposure limits (i.e., $10 \mathrm{mrem} / \mathrm{yr}$. airborne). However, under the as low as reasonably achievable (ALARA) principle, Tritium releases to the environment will be reduced through the use of a collection system. With this system, releases will occur from normal NIF clean-up and maintenance operations, and will be below $10 \mathrm{Ci} / \mathrm{yr}$ for the baseline case and less than $30 \mathrm{Ci} / \mathrm{y}$ for the enhanced envelope.

\subsubsection{Direct Radiation and Skyshine}

The direct radiation intensity outside the building was calculated with the assumption that the chamber is $0.1-\mathrm{m}$-thick $\mathrm{Al}$, surrounded by a 0.4 -m-thick layer of concrete shielding, 1.8-m-thick ordinary concrete wall and $1.2-\mathrm{m}$ thick concrete roof. The target room is $30.5 \mathrm{~m}$ in diameter by $29.3-\mathrm{m}$ tall. The D-T source term for the baseline case is $1.4 \times 10^{20}$ neutrons, and for the enhanced envelope the source term is $4.4 \times 10^{20}$ neutrons. The combined direct and skyshine dose-equivalents as a function of distance from the center of the target area building are shown in Fig. 1. 


\subsubsection{NIF Radionuclide Inventory}

The inventory of radionuclides in the NIF is provided in Table 2-7 (Note: the values in Table 2-7 are undergoing check and should be considered preliminary).

Table 2-7. NIF estimated maximum radionuclide inventory.

\begin{tabular}{|c|c|}
\hline Isotope & Quantity (Ci) \\
\hline \multicolumn{2}{|c|}{ Exhaust collection system } \\
\hline $3 \mathrm{H}$ & $300 \mathrm{C}$ \\
\hline \multicolumn{2}{|c|}{ Activated particulate } \\
(end of year, after 20-M) shot prior to cleanup) \\
\hline $24 \mathrm{Na}$ & $9.5 \mathrm{E}-3$ \\
\hline $27 \mathrm{Mg}$ & 0.63 \\
\hline $28 \mathrm{Al}$ & 1.2 \\
\hline $29 \mathrm{Al}$ & $5.7 \mathrm{E}-4$ \\
\hline $52 \mathrm{~V}$ & 1.2 \\
\hline $55 \mathrm{Cr}$ & 0.58 \\
\hline $56 \mathrm{Mn}$ & 0.14 \\
\hline $60 \mathrm{~m} \mathrm{Co}$ & 2.0 \\
\hline $60 \mathrm{Co}$ & $4.7 \mathrm{E}-6$ \\
\hline $62 \mathrm{~m} \mathrm{Co}$ & 0.21 \\
\hline $62 \mathrm{Cu}$ & 42 \\
\hline $64 \mathrm{Cu}$ & 0.51 \\
\hline $66 \mathrm{Cu}$ & 0.12 \\
\hline $196 \mathrm{Au}$ & $9.0 \mathrm{E}-2$ \\
\hline
\end{tabular}

a These are maximum inventories expected for any configuration, and correspond to a $5 \mathrm{~m}$ radius chamber.

b Activation of gold target is greater than for lead target.

c For the enhanced envelope the ${ }^{3} \mathrm{H}$ inventory is $500 \mathrm{Ci}$. 
Table 2-7 (continued). NIF estimated maximum radionuclide inventory.

\begin{tabular}{|c|c|}
\hline Isotope & Quantity (Ci) \\
\hline \multicolumn{2}{|c|}{$\begin{array}{c}\text { Activated particulate } \\
\text { (end of year, after 20-M] shot prior to cleanup) }\end{array}$} \\
\hline $57 \mathrm{Ni}$ & $1.5 \mathrm{E}-5$ \\
\hline $63 \mathrm{Zn}$ & $8.5 \mathrm{E}-5$ \\
\hline${ }^{197} \mathrm{Pt}$ & $6.1 \mathrm{E}-4$ \\
\hline${ }^{198} \mathrm{Au}$ & $9.9 \mathrm{E}-4$ \\
\hline $16 \mathrm{~N}$ & 32 \\
\hline${ }^{58} \mathrm{Co}$ & $2.6 \mathrm{E}-6$ \\
\hline${ }^{51} \mathrm{Cr}$ & $2.0 \mathrm{E}-4$ \\
\hline $54 \mathrm{Mn}$ & $1.1 \mathrm{E}-4$ \\
\hline \multicolumn{2}{|c|}{$\begin{array}{c}\text { Activated air } \\
\text { (after 20-MJ shot-time 0) }\end{array}$} \\
\hline Isotope & Quantity (Ci) \\
\hline $3_{\mathrm{H}}$ & $6.8 \mathrm{E}-5$ \\
\hline $13 \mathrm{~N}$ & 8.7 \\
\hline $16 N$ & $1.2 \mathrm{E} 3$ \\
\hline $37_{S}$ & 0.25 \\
\hline $40 \mathrm{Cl}$ & 0.94 \\
\hline${ }^{41} \mathrm{Ar}$ & 1.4 \\
\hline${ }^{14} \mathrm{C}$ & 2.4E-5 \\
\hline
\end{tabular}

\subsubsection{Nonradioactive Atmospheric Emissions}

The radioactive atmospheric emissions discussed in the previous sections are listed in Table 2-7. Nonradioactive atmospheric emissions anticipated for normal NIF operation (baseline and enhanced envelope are the same) are listed in Table $2-8$. The volatile organic compounds (VOCs) are mainly from solvents used in 
cleaning operations.

Table 2-8. Nonradioactive atmospheric emissions.

(Same for baseline and enhanced envelope.)

\begin{tabular}{|l|l|}
\hline NIF gas & $\begin{array}{l}\text { Quantity } \\
\text { per year }\end{array}$ \\
\hline Argon & $2,600,0001 / \mathrm{y}$ \\
\hline Nitrogen & $4,500,000 \mathrm{~m}^{3} / \mathrm{y}$ \\
\hline Helium & $3,000 \mathrm{~m}^{3} / \mathrm{y}$ \\
\hline VOCs* & $500 \mathrm{~kg} / \mathrm{y}$ \\
\hline
\end{tabular}

*Divided LTAB 125 kg/y; OAB 375 kg/y

\subsubsection{Nonradioactive Hazardous Chemical Inventory}

The nonradioactive hazardous chemical inventory is shown in Table 2-9a and Table 2-9b.

Table 2-9a. NIF Baseline estimated chemical inventories.

\begin{tabular}{|c|c|c|}
\hline Chemical & Source & Quantity \\
\hline Acetone & $\begin{array}{l}\text { Solvent for } \\
\text { cleaning }\end{array}$ & $10 \mathrm{gal}(30 \mathrm{~kg})$ \\
\hline Alumina & $\begin{array}{l}\text { Particulates from } \\
\text { first wall }\end{array}$ & $6.7 \mathrm{~kg}$ \\
\hline $\begin{array}{l}\text { Ammonium hydroxide } \\
(50 \% \text { wt) }\end{array}$ & Optics treatment & $\begin{array}{l}38 \mathrm{~kg}[10 \mathrm{gal} \\
(\sim 85 \mathrm{lb})] \\
\text { ammonia- } \\
\text { equivalent). }\end{array}$ \\
\hline Copper & $\begin{array}{l}\text { Particulates from } \\
\text { cryostat }\end{array}$ & $<0.5 \mathrm{~kg}$ \\
\hline Ethanol & $\begin{array}{l}\text { Solvent for } \\
\text { cleaning and } \\
\text { optics treatment }\end{array}$ & $\begin{array}{l}1200 \mathrm{~kg}(400 \\
\text { gal) }\end{array}$ \\
\hline Gold & $\begin{array}{l}\text { Particulates from } \\
\text { hohlraum }\end{array}$ & $<1 \mathbf{~ k g}$ \\
\hline $\begin{array}{l}\text { Hydrofluoric acid } \\
\text { (50 gal at } 1 \% \text { wt, } \\
5 \text { gal at } 52 \% \text { wt) }\end{array}$ & Optics treatment & $\begin{array}{l}22 \mathrm{~kg} \text { HF [55 gal } \\
(\sim 50 \mathrm{bb})]\end{array}$ \\
\hline Mercury & Ignitrons & $\begin{array}{l}1290 \mathrm{~kg}[25 \mathrm{gal} \\
(\sim 2840 \mathrm{bb})]\end{array}$ \\
\hline $\begin{array}{l}\text { Sodium hydroxide ( } 50 \\
\text { gal at } 3 \% \text { wt, } 20 \text { gal at } \\
50 \% \text { wt, or solid pellets) }\end{array}$ & $\begin{array}{l}\text { Cleaner for } \\
\text { debris shields }\end{array}$ & $\begin{array}{l}82 \mathrm{~kg}[70 \mathrm{gal} \\
(\sim 180 \mathrm{lb} \\
\mathrm{NaOH})]\end{array}$ \\
\hline Stainless steel & $\begin{array}{l}\text { Particulates from } \\
\text { target } \\
\text { positioner }\end{array}$ & $<0.2 \mathrm{~kg}$ \\
\hline Tetraethylorthosilicate & Optics treatment & $353 \mathrm{~kg}(100 \mathrm{gal})$ \\
\hline
\end{tabular}


Table 2-9b. NIF Enhanced Envelope estimated chemical inventories.

\begin{tabular}{|c|c|c|}
\hline Chemical & Source & Quantity \\
\hline$\overline{\text { Acetone }}$ & $\begin{array}{l}\text { Solvent for } \\
\text { cleaning }\end{array}$ & $30 \mathrm{~kg}(10 \mathrm{gal})$ \\
\hline Alumina & $\begin{array}{l}\text { Particulates from } \\
\text { first wall }\end{array}$ & $29.6 \mathrm{~kg}$ \\
\hline $\begin{array}{l}\text { Ammonium hydroxide } \\
(50 \% \text { wt) }\end{array}$ & Optics treatment & $\begin{array}{l}138 \mathrm{~kg} \text { [10 gal } \\
\text { ( 85 fb } \\
\text { ammonia- } \\
\text { equivalent)] }\end{array}$ \\
\hline Copper & $\begin{array}{l}\text { Particulates from } \\
\text { cryostat }\end{array}$ & $<0.9 \mathrm{~kg}$ \\
\hline Ethanol & $\begin{array}{l}\text { Solvent for } \\
\text { cleaning and } \\
\text { optics treatment }\end{array}$ & $1200 \mathrm{~kg}$ (400 gal) \\
\hline Gold & $\begin{array}{l}\text { Particulates from } \\
\text { hohlraum }\end{array}$ & $<1.7 \mathrm{~kg}$ \\
\hline $\begin{array}{l}\text { Hydrofluoric acid } \\
\text { (50 gal at } 1 \% \text { wt, } \\
5 \text { gal at } 52 \% \text { wt) }\end{array}$ & Optics treatment & $\begin{array}{l}22 \mathrm{~kg}[55 \mathrm{gal} \\
\text { ( } 50 \mathrm{lb} \mathrm{HF})]\end{array}$ \\
\hline Mercury & Ignitrons & $\begin{array}{l}1290 \mathrm{~kg}[25 \mathrm{gal} \\
(\sim 2840 \mathrm{bb}])\end{array}$ \\
\hline $\begin{array}{l}\text { Sodium hydroxide ( } 50 \\
\text { gal at } 3 \% \text { wt, } 20 \text { gal at } \\
50 \% \text { wt, or solid pellets) }\end{array}$ & $\begin{array}{l}\text { Cleaner for debris } \\
\text { shields }\end{array}$ & $\begin{array}{l}82 \mathrm{~kg}[70 \mathrm{gal} \\
(\sim 180 \mathrm{lb} \\
\mathrm{NaOH})]\end{array}$ \\
\hline Stainless steel & $\begin{array}{l}\text { Particulates from } \\
\text { target } \\
\text { positioner }\end{array}$ & $<0.6 \mathrm{~kg}$ \\
\hline Tetraethylorthosilicate & Optics treatment & $353 \mathrm{~kg}(100 \mathrm{gal})$ \\
\hline
\end{tabular}


Annual exposure level, mrem

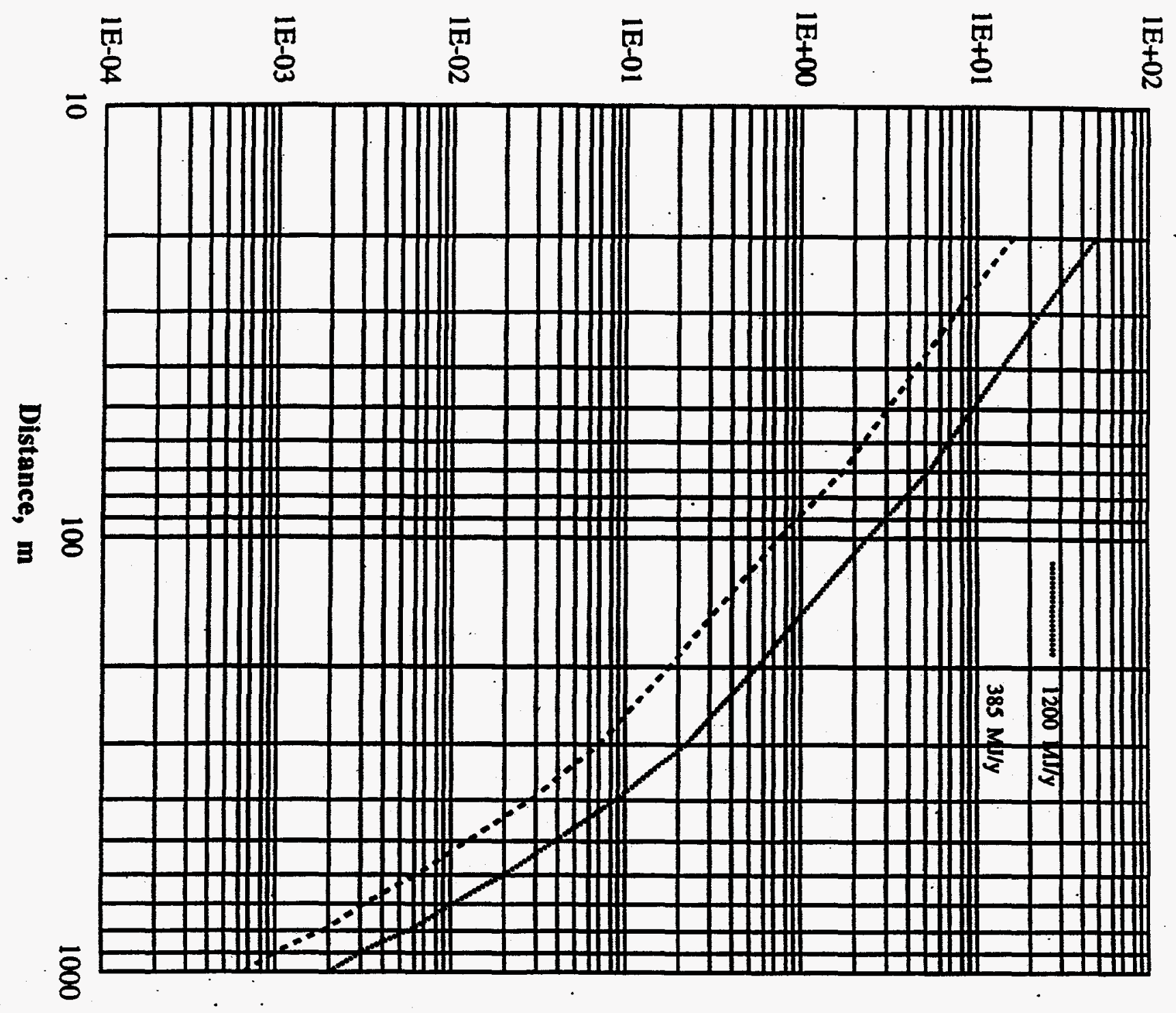

Fig. 1. Prompt radiation (direct plus skyshine) for the baseline ( $385 \mathrm{MJ} / \mathrm{y})$ and the enhanced case $(1200 \mathrm{MJ} / \mathrm{y})$.

\subsubsection{Potential Accidents}

Section to be covered by three letters from Sandra Brereton addressing:

a. Bounding radiological accidents

b. Impacts within $100 \mathrm{~m}$ (i.e., effect of short lived isotopes)

c. Chemical release accidents

\subsubsection{NIF Decontaminatin and Decommissioning}

Section to be covered by letter from Mike Tobin. 


\subsection{NIF Operational Personnel}

\subsubsection{NIF Operational Philosophy}

Based on current experience, it is anticipated that the NIF will be operated 24 hours a day seven days a week in order to achieve an acceptable shot rate to support activation and operations leading to ignition. After ignition, the operating hours may drop to two shifts (16 hours) per day, five days per week. For additional information on NIF operating requirements, refer to the NIF Functional Requirements.

The following two sections provide estimates of the number of personnel required to support the NIF along with brief descriptions of the qualifications, specialized skills, and experience required of these personnel. These estimates are provided to give potential sites considering NIF a general idea of the personnel resource support required. These estimates do not include general sitesupport personnel such as security, fire department, human resources, medical, food service, waste management, procurement, accounting, receiving, plant engineering (crafts), or transportation.

In the following two sections, installation refers to the period of time beneficial occupancy of the LTAB and preceding Key Decision No. 4 (KD4). This is the time when the laser and target systems will be installed and brought up to operational status. During this time, some laser issues such as beam line gains, transmissions, frequency conversion efficiencies, pulse shaping characteristics and laser damage will be addressed and laser performance verified. Performance of the initial set of target diagnostics required to begin ICF indirect drive experiments will also be verified. These performance tests and verifications lead to the final operational readiness review.

\subsubsection{Engineering, Operations, and Maintenance Support Personnel}

Engineering, operations, and maintenance support personnel will be required during both installation of the NIF components, and for ongoing operation and maintenance of the building. Personnel required to support off-site activities such as diagnostics development are not included in this document. These personnel estimates are presented here in two major groups: mechanical support and electrical support. In addition to the standard breakdown for these groups, the mechanical group includes clean room and optics personnel, and the electrical group includes computer support and laser system operation. A brief description of the job classifications in these two groups is included in Appendix A.

For these estimates, the NIF is assumed to be staffed for 16 to 24 hours per day, 7 days per week during both installation and operation. Personnel will be used during installation to check out system components and perform needed 
modifications. After KD4, a smaller number of personnel will be required to support ongoing operations, maintenance, and building modifications.

The baseline estimates of engineering, operations, and maintenance support personnel for the two cases (pre-KD4 installation, and post-KD4 operation) are shown in Table 2-16. Engineering personnel needed for component design would decrease during the transition from installation to operation. However, there would still be a need to maintain and upgrade the system with a smaller number of these personnel, even after operation commences. Similarly, personnel needed for operation and maintenance will increase during the same period. Many of the personnel assigned installation responsibilities could be transferred to operational duties. The installation column in Table 2-16 includes TEC funded installation plus OPC funded activation, and represents the peak year FY01.

The personnel requirements to support installation and activation of the equipment (pre-KD4) would not increase for the Enhanced Envelope. However, post-KD4 operations would require additional technicians to support the expanded maintenance requirements. An additional 40 Mechanical Technicians and 10 Electrical Technicians would be added to the Operation column in Table 2-16. 
Table 2-16. NIF engineering, operations, and maintenance support.

\begin{tabular}{|c|c|c|}
\hline Position/Task & Installation & Operation \\
\hline $\begin{array}{l}\text { Mechanical Engineering } \\
\text { Lead Engineers } \\
\text { Engineers } \\
\text { Lead Designers } \\
\text { Designers } \\
\text { Technical Coordinators }\end{array}$ & 76 & 20 \\
\hline $\begin{array}{l}\text { Mechanical Technicians } \\
\text { Technician Supervisors } \\
\text { Coatings/Measurements Technicians } \\
\text { Clean Room Assembly Technicians } \\
\text { Contamination Control Technicians } \\
\text { Machinists } \\
\text { Laser Bay Technicians } \\
\text { Target Bay Technicians } \\
\text { Switch Yard Technicians } \\
\text { General Installation Technicians } \\
\text { Diagnostic Support Technicians } \\
\text { Diagnostic Coordinators } \\
\text { Target Handlers }\end{array}$ & 136 & 116 \\
\hline Total Mechanical Personnel & 212 & 136 \\
\hline
\end{tabular}


Table 2-16 (continued). NIF engineering, operations, and maintenance support.

\begin{tabular}{|c|c|c|}
\hline Position/Task & Installation & Operation \\
\hline $\begin{array}{l}\text { Electrical Engineering } \\
\text { Lead Engineers } \\
\text { Engineers } \\
\text { Safety Officer } \\
\text { Computer Scientists } \\
\text { Lead Designer } \\
\text { Designers } \\
\text { Technical Coordinators }\end{array}$ & 56 & 26 \\
\hline $\begin{array}{l}\text { Electrical Technicians } \\
\text { Technician Supervisors } \\
\text { Diagnostic Development Technicians } \\
\text { Power Conditioning Technicians } \\
\text { System Alignment Technicians } \\
\text { Laser Diagnostic Technicians } \\
\text { Front End Technicians } \\
\text { Target Diagnostic Technicians } \\
\text { Technical Photography Technicians } \\
\text { Controls Technicians } \\
\text { General Installation Technicians } \\
\text { Safety Technicians } \\
\text { Data Processing Technicians } \\
\text { EE Shop Technicians } \\
\text { Optics Inventory Technicians }\end{array}$ & 91 & 105 \\
\hline Total Electrical Personnel & 147 & 131 \\
\hline Mechanical and Electrical Total & 359 & 267 \\
\hline
\end{tabular}




\subsubsection{Scientific Personnel}

This section provides an estimate of the number of scientific personnel required to be resident at the NIF site. These personnel will provide support to other visiting scientists performing experiments at the facility. Target diagnosticians will be needed to insure quality data from the facility diagnostics, and to provide preliminary data analysis between shots. Target designers will be required to provide on-site design and analysis work to allow immediate feedback to experimenters on pre-shot issues such as target quality, target and laser beam alignment etc., as well as immediate post shot design feedback. Laser scientists will be required on-site to support diagnostics which measure beam energies, powers, near-field profiles, farfield profiles, and pointing on target. These diagnostics will need to be proven and periodically cross-checked with other measurements and with models. Laser scientists will also be required to address laser system performance issues in support of day-to-day operations at the facility.

Table 2-17 shows the baseline estimated scientific support staff for the NIF. A brief description of the job requirements for each of these scientists are included in Appendix B. An additional 10 scientists would be required to support analysis of the additional data from the Enhanced Envelope Case.

Table 2-17. NIF scientific support.

\begin{tabular}{|c|c|}
\hline Type & On-Site \\
\hline $\begin{array}{l}\text { Scientific Director } \\
\text { Lab Liaison } \\
\text { Shot Physicist } \\
\text { Laser Scientific Manager } \\
\text { Laser System Scientist } \\
\text { Laser System Analyst } \\
\text { Plasma Physicist. } \\
\text { Capsule Designer } \\
\text { Hohlraum Designer } \\
\text { Cryogenic Scientist } \\
\text { Material Scientist } \\
\text { Laser Diagnostic Scientist } \\
\text { Optical Damage Scientist } \\
\text { Oscillator and Preamplifier Scientist } \\
\text { X-ray Diagnostician } \\
\text { Optical Diagnostician } \\
\text { Neutron Diagnostician } \\
\text { Fast Timing Scientist } \\
\text { Nonlinear Optical Scientist } \\
\text { Nonlinear Optics Analyst }\end{array}$ & $\begin{array}{l}1 \\
3 \\
5 \\
1 \\
6 \\
2 \\
2 \\
2 \\
2 \\
2 \\
1 \\
1 \\
2 \\
2 \\
3 \\
3 \\
7 \\
7 \\
7 \\
2 \\
3 \\
1\end{array}$ \\
\hline Total Number of Scientists & 60 \\
\hline
\end{tabular}




\subsection{Support Equipment}

To accomplish the activation, operation, and maintenance of the NIF, specialized equipment will be required that is not a part of the experimental systems. Some of this equipment may require special environmental conditions for operation (i.e., temperature, humidity, and vibration control). The list presented in Table 2-18 provides the initial evaluation of the equipment required. Where manufacturing names are used, it is for example only and an equivalent equipment can be substituted. This list will be revised at the completion of the NIF CDR.

This equipment falls into three categories:

1) Equipment which is dedicated and required to meet the NIF functional requirements and primary criteria;

2) Equipment which is dedicated to and required for general aspects of NIF operation;

3) Equipment which is not dedicated but which will be used by NIF and other host site buildings (e.g., general analytical equipment).

Table 2-18. NIF support equipment.

\begin{tabular}{|c|c|c|c|}
\hline Quantity & Equipment item & $\begin{array}{l}\text { Building } \\
\text { location }\end{array}$ & $\begin{array}{l}\text { Equipment } \\
\text { category } \\
\end{array}$ \\
\hline 1 & Scanning electron microscope & Optics Laboratory & 3 \\
\hline 4 & $\begin{array}{l}\text { Optical microscopes } \\
\text { Laser damage testing }\end{array}$ & & 3 \\
\hline 6 & $\begin{array}{l}-\quad \text { Lasers }(1 W / 3 W, 3-49) \text { - Continuum } \\
\text { (NY 82-3) }\end{array}$ & & 2 \\
\hline 6 & - Beam profiler - Big Sky (BCVIS - 4) & & 2 \\
\hline 6 & - Microscope and stage - Olympus (Nomarski) & & 2 \\
\hline 2 & $\begin{array}{l}\text { - Atomic force microscope - Digital } \\
\text { Instruments } \\
\text { Optics conditioning }\end{array}$ & & 2 \\
\hline 1 & $\begin{array}{l}\text { - Computerized large translation stage - } \\
\text { Newport/Klinger (custom) }\end{array}$ & & 2 \\
\hline 1 & $\begin{array}{l}\text { - } \quad \text { Laser }(1 W / 3 W) \text { - Continuum } \\
\text { (NY 82-3) }\end{array}$ & & 2 \\
\hline 1 & - Beam profiler - Big Sky (BCVIS - 4) & & 2 \\
\hline 1 & - Clean hood servicer (custom) & & 2 \\
\hline
\end{tabular}


Table 2-18 (continued). NIF support equipment.

\begin{tabular}{|c|c|c|c|}
\hline Quantity & Equipment item & $\begin{array}{l}\text { Building } \\
\text { location }\end{array}$ & $\begin{array}{l}\text { Equipment } \\
\text { category }\end{array}$ \\
\hline 4 & $\begin{array}{l}\text { Phase measuring interferometers: two capable of } \\
\text { measuring up to } 50-\mathrm{cm} \text { aperture and two capable of } \\
\text { measuring up to } 20-\mathrm{cm} \text { aperture; equivalent to Zygo } \\
\text { Mark IVxp, Wyko } 6000 \text { or MiniFIZ (Phase Shift } \\
\text { Technology Inc.) with computer and software for data } \\
\text { analysis equal to Metropro (Zygo Corp.), WISP II } \\
\text { (Wyko Corp.) or Opticode (Phase Shift Technology } \\
\text { Inc.) }\end{array}$ & $\begin{array}{l}\text { Optics Laboratory } \\
\text { (cont.) }\end{array}$ & 2 \\
\hline 1 & $\begin{array}{l}\text { Large aperture interferometer for static fringe analysis: } \\
\text { equivalent to the Zygo Large Aperture Sytem, with } \\
\text { fringe analysis equivalent to ZAPP (Zygo Automatic } \\
\text { Pattern Processor) }\end{array}$ & & 3 \\
\hline 1 & $\begin{array}{l}\text { Non contact surface profiler: equivalent to Maxim 3D } \\
\text { Model 5700/5800 (Zygo Corp.), Hi Res TOPO 3D } \\
\text { system (Wyko Corp.), or MicroXAM (Phase Shift } \\
\text { Technology) with computer and software for data } \\
\text { analysis equivalent to Metropro (Zygo Corp.), TOP 3D } \\
\text { (Wk Corp.) or Mapvue (Phase Shift Technology Inc.) }\end{array}$ & & 3 \\
\hline 1 & $\begin{array}{l}\text { An extended range non contact surface profiler: } \\
\text { capable of measuring "rough" surfaces; equivalent to } \\
\text { Maxim NT (Zygo Corp.), Model RST (Wydo Corp.) or } \\
\text { MicroXAM-EX (Phase Shift Technology) with } \\
\text { computer and software for data analysis }\end{array}$ & & 3 \\
\hline 1 & $\begin{array}{l}15-50 \text {-cm aperture photometer: (currently not a } \\
\text { commercial item), capable of measuring reflectance, } \\
\text { transmission and scatter of massive, large aperture } \\
\text { optics at } 0.351 \text { and at } 1.054 \text { - } \mu \text { m wavelengths. This } \\
\text { instrument can perform measurement either by: } \\
\text { a) rastering the optic through a probe beam and } \\
\text { recording the reflected and/or transmitted beams at } \\
\text { each point on the optic, or } \\
\text { b) by using a full aperture beam and a telescope with } \\
\text { an imaging photo diode array to image the entire optic } \\
\text { at once. }\end{array}$ & & 2 \\
\hline 3 & $\begin{array}{l}\text { Polishing/grinding machines: for reworking debris } \\
\text { shields. }\end{array}$ & & 3 \\
\hline
\end{tabular}


Table 2-18 (continued). NIF support equipment.

\begin{tabular}{|c|c|c|c|}
\hline Quantity & Equipment item & $\begin{array}{l}\text { Building } \\
\text { location }\end{array}$ & $\begin{array}{l}\text { Equipment } \\
\text { category }\end{array}$ \\
\hline 1 & $\begin{array}{l}50 \text {-cm aperture polariscope: (currently not a } \\
\text { commercial item), capable of measuring stress } \\
\text { birefringence of massive large aperture optics. It } \\
\text { consists of a He-Ne laser light source, beam expander, } \\
\text { two thin film polarizers and two quarterwave plates, } \\
\text { followed by an imaging telescope and photodiode } \\
\text { array for imaging. This instrument can perform } \\
\text { measurements by rastering or by imaging the full } \\
\text { aperture, as described for the photometer. }\end{array}$ & $\begin{array}{l}\text { Optics Laboratory } \\
\text { (cont.) }\end{array}$ & 2 \\
\hline 3 & Autocollimators & & 2 \\
\hline $\begin{array}{l}1 \\
1 \\
1 \\
1 \\
1 \\
1\end{array}$ & $\begin{array}{l}\text { Cryogenic dewars - Nitrogen/Helium - } 2501 \\
\text { Target metrology system } \\
\quad \text { - Target manipulator } \\
\quad \text { Viewing system } \\
\text { - Measuring and alignment } \\
\text { Sputter desposition coater - Beryllium } \\
\text { Evaporative coater } \\
\text { E-beam evaporative coater } \\
\text { Multistage sputtering deposition systems } \\
\text { Liquid scintillation system (tritium counter) } \\
\quad \text { - Beckman Model LS } 6500 \text { or equivalent } \\
\quad \text { - Perkin-Elmer PDS Microdesitometer 1010GM } \\
\text { Target assembly station } \\
\text { Cryogenic station } \\
\text { Cryogenic layering support equipment } \\
\text { Optical microscope }\end{array}$ & $\begin{array}{l}\text { Target Receiving, } \\
\text { Inspection, Storage } \\
\text { and Repair } \\
\text { Building }\end{array}$ & $\begin{array}{l}3 \\
3 \\
3 \\
3 \\
3 \\
3 \\
3 \\
1 \\
2 \\
1 \\
3 \\
\end{array}$ \\
\hline $\begin{array}{l}1 \\
1 \\
1 \\
1\end{array}$ & $\begin{array}{l}\text { Technology photography darkroom } \\
\text { - Hope processor } \\
\text { - Iford print processor or equivalent } \\
\text { - Enlarger/lenses } \\
\text { - Drum processor - Tabo or Wing-lynch } \\
\text { Forklifts } \\
\text { - 1.5-ton electric powered } \\
\text { - 2-ton propane powered } \\
\text { - } \text { 6-ton gasoline powered } \\
\text { Scissors-type man lifts, battery powered, 1000-lb } \\
\text { capacity, clean room compatible } \\
\text { - 19-ft vertical extension, narrow width } \\
\text { - 19-ft vertical extension, standard width }\end{array}$ & $\begin{array}{l}\text { Laser and Target } \\
\text { Area Building }\end{array}$ & $\begin{array}{l}3 \\
3 \\
3 \\
3 \\
2 \\
2 \\
2\end{array}$ \\
\hline
\end{tabular}


Table 2-18 (continued). NIF support equipment.

\begin{tabular}{|c|c|c|c|}
\hline Quantity & Equipment item & $\begin{array}{l}\text { Building } \\
\text { location }\end{array}$ & $\begin{array}{l}\text { Equipment } \\
\text { category }\end{array}$ \\
\hline $\begin{array}{l}5 \\
3 \\
4 \\
3 \\
2 \\
3 \\
1 \\
2 \\
4 \\
2 \\
5\end{array}$ & $\begin{array}{l}\text { Mobile crane } \\
\text { - } 10 \text {-ton, truck mounted, } 50 \text {-ft boom } \\
\text { Vacuum repair equipment } \\
\text { - Cryo bakeout oven } \\
\text { - } \text { 8-station cryo flow bench } \\
\text { - Portable helium leak detectors } \\
\text { - Portable turbo carts, } 500 \text { CFM } \\
\text { Pulsed power component tester } \\
\text { - } 300 \text { kJ bank, in addition to charging, } \\
\text { switching and dummy loads to test up to } 2 \\
\text { - MJ of capacitors simultaneousiy } \\
\text { - Appropriate safety barriers, control and } \\
\text { interlock systems } \\
\text { Radiation detection/measurement instruments } \\
\text { - Tritium monitors (portable) } \\
\text { - Ion chambers } \\
\text { - G-M counters } \\
\text { - Remote area monitors } \\
\text { - Portal unit (beta/gamma) } \\
\text { - } \text { HR meter } \\
\text { - Liquid scintillation counter } \\
\text { - Neutron monitors } \\
\text { - HTO air samplers } \\
\text { - Vacuum pump exhaust monitors } \\
\text { - Tritium, neutron, gamma monitors } \\
\text { Safety capacitor forklift: This device would be used to } \\
\text { maintain the capacitor bank thoughout its life. The } \\
\text { capacitors are too heavy to lift by hand, so a modified } \\
\text { device would need to be "man-rated" so that } \\
\text { personnel could connect the fixture to the capacitor. } \\
\text { The rating would need to be at least } 600 \text { lb. }\end{array}$ & $\begin{array}{l}\text { Laser and Target } \\
\text { Area Building } \\
\text { (cont.) }\end{array}$ & $\begin{array}{l}2 \\
2 \\
2 \\
2 \\
2 \\
2 \\
2 \\
2 \\
2 \\
2 \\
2 \\
2\end{array}$ \\
\hline $\begin{array}{l}1 \\
1\end{array}$ & $\begin{array}{l}\text { Specialized electronic equipment } \\
\begin{array}{l}\text { Network analyzer - Hewlett Packard } 8510 \mathrm{C} \\
-\quad 45 \mathrm{MHz}-50 \mathrm{GHz} \text { S-parameter test set }-\mathrm{H} / \mathrm{P} \\
8517 \mathrm{~A}\end{array}\end{array}$ & $\begin{array}{c}\text { Electronic } \\
\text { Calibration } \\
\text { (electrical shop) }\end{array}$ & $\begin{array}{l}3 \\
3\end{array}$ \\
\hline
\end{tabular}


Table 2-18 (continued). NIF support equipment.

\begin{tabular}{|c|c|c|c|}
\hline Quantity & Equipment item & $\begin{array}{l}\text { Building } \\
\text { location }\end{array}$ & $\begin{array}{l}\text { Equipment } \\
\text { category }\end{array}$ \\
\hline 1 & $\begin{array}{l}-\quad 45 \mathrm{MHz}-50 \mathrm{GHz} \text { synthesized sweeper }-\mathrm{H} / \mathrm{P} \\
83651 \mathrm{~A}\end{array}$ & $\begin{array}{c}\text { Electronic } \\
\text { Calibration } \\
\text { (electrical shop) }\end{array}$ & 3 \\
\hline 10 & $\begin{array}{l}\text { 4-5GHz transient digitizing oscilloscope - } \\
\text { Tekronix SCD } 5000\end{array}$ & & 3 \\
\hline 4 & $\begin{array}{l}\text { - Picosecond light pulser - Hamamatsu Model } \\
\text { C1308. }\end{array}$ & & 3 \\
\hline 2 & $\begin{array}{l}\text { - Optical TDR - Opto-Electronics Model OFM- } \\
20-850 \mathrm{~mm}-50-5 T\end{array}$ & & 3 \\
\hline 6 & - EG\&G optical time mark generator $3 \mathrm{GHz}$ & & 3 \\
\hline $\begin{array}{l}1 \\
1 \\
1 \\
1 \\
1 \\
1 \\
1\end{array}$ & $\begin{array}{l}\text { Machine tools } \\
\text { Equipment required for a precision machine shop } \\
\text { Lathes, mills, etc. the largest of which is shown below } \\
- \text { Mill, vertical spindle } \mathrm{CNC}, 30 \times 50 \text {-in. table } \\
- \text { Mill, horizontal boring } 36 \times 60 \text {-in. table } \\
- \text { Mill, horizontal boring } \mathrm{CNC}, 72 \times 96 \text {-in. table } \\
- \text { Lathe, } 36 \text {-in. vertical turret } \\
\text { - Drill press, } 60 \text {-in. radial arm } \\
\text { - Optical compariator, large } \\
\text { Inspection tools: (indicators, profilometers, surface } \\
\text { inspection, Microheight gage, granite tables, depth } \\
\text { gages, Cordax true position measure machine, } \\
\text { calibration standards with temperature control). }\end{array}$ & Machine Shop & $\begin{array}{l}3 \\
3 \\
3 \\
3 \\
3 \\
3 \\
3 \\
3 \\
3\end{array}$ \\
\hline $\begin{array}{c}25 \\
75 \\
100 \\
50 \\
10 \\
10 \\
1 \\
2 \\
3\end{array}$ & $\begin{array}{l}\text { Computers and peripheral equipment } \\
\text { - SPARC } 10 \text { - or equivalent at } \\
\text { - Macintosh } 800 \text { - or equivalent at } \\
\text { - Macintosh } 650 \text { - or equivalent at } \\
\text { - Laser printers } \\
\text { - Color printer } \\
\text { - Scanner/digitizer } \\
\text { NSA approved data encryption device: } 1.5 \\
\text { megabit/sec. } \\
\text { - Color inkjet plotter, E-size } \\
\text { - High speed plotter, E-size, Cal Comp } \\
\text { Drawing Maser Plus or equivalent }\end{array}$ & Technical Offices & $\begin{array}{l}2 \\
2 \\
2 \\
2 \\
2 \\
2 \\
2 \\
2 \\
2\end{array}$ \\
\hline 1 & $\begin{array}{l}\text { Flashlamp Test Building } \\
\text { - Capacitor bank systems, with controls and } \\
\text { interlocks for unattended operation. Three } \\
\text { would be required for infant mortality, lamp } \\
\text { cassette and life testing. Roughly } 1 \mathrm{MJ} \text { at } 24 \\
\mathrm{kV} \text { is required for each bank } \\
\text { - } \text { Hi-pot tester, at least } 60-\mathrm{kV}, 5 \text {-mA capacity }\end{array}$ & Assembly Building & 1 \\
\hline
\end{tabular}


Table 2-18 (continued). NIF support equipment.

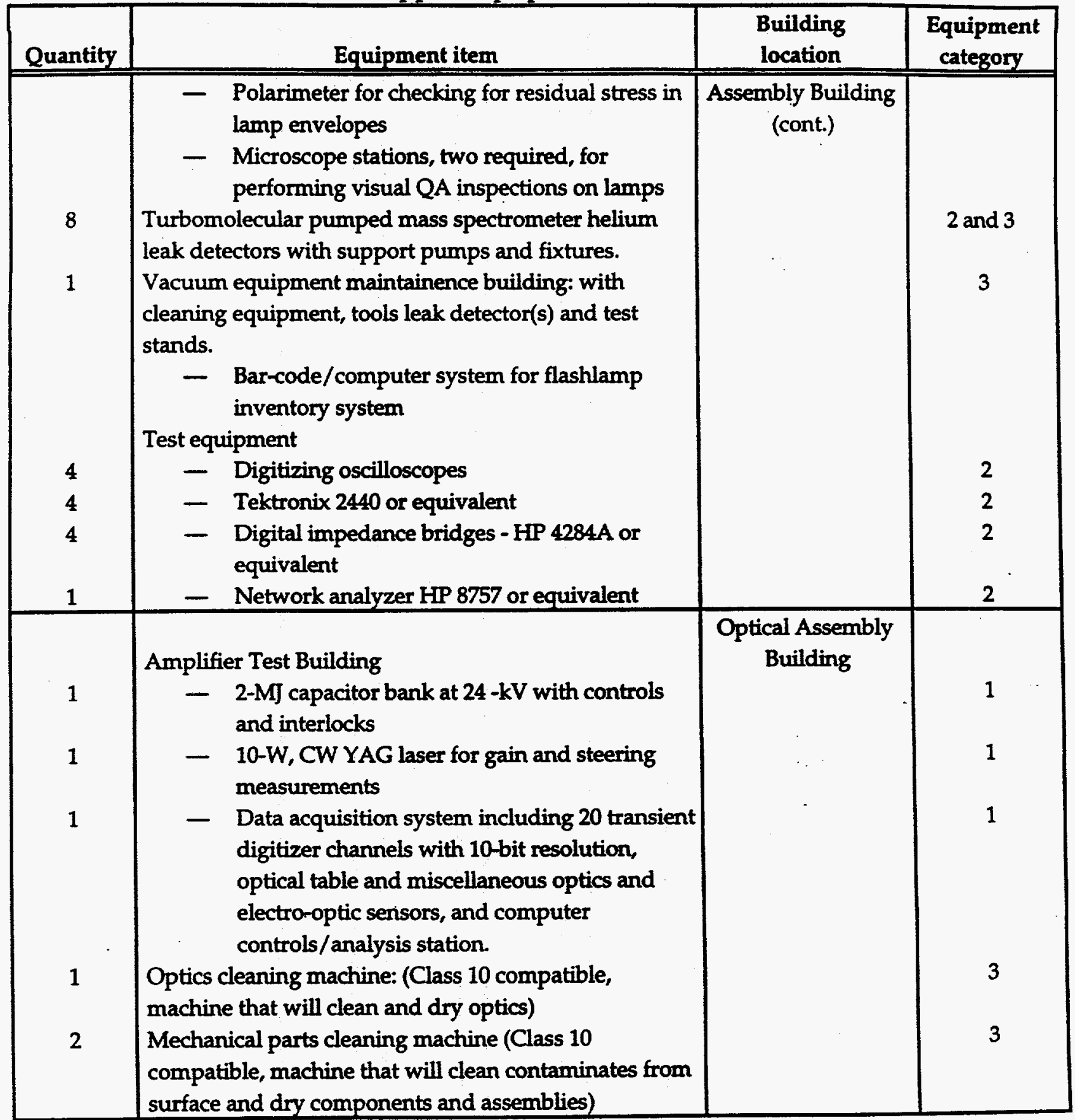




\section{NIF Building Descriptions}

\subsection{Laser and Target Area Building}

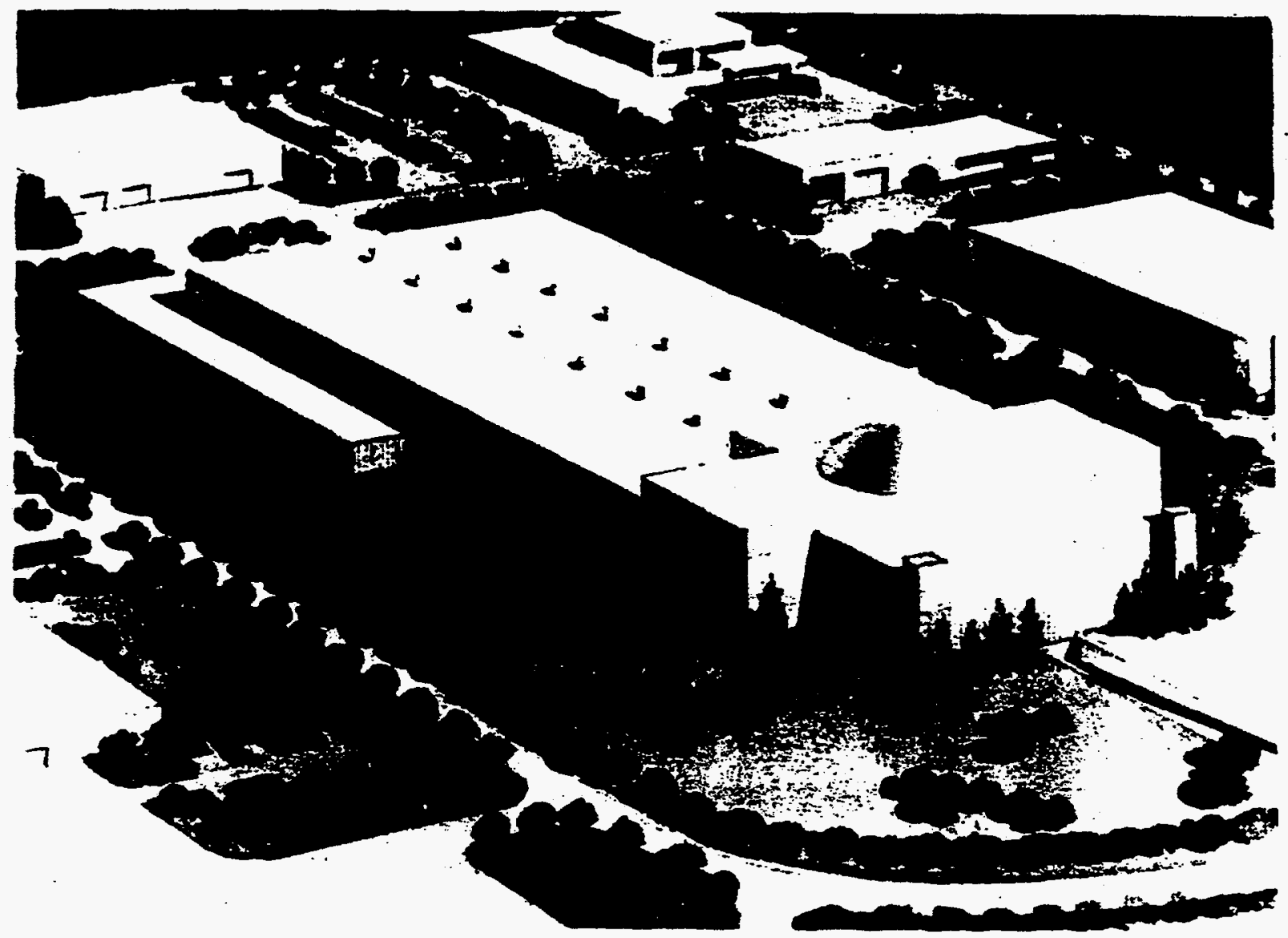

Functional description: Laboratory to provide environmental conditions for the NIF laser, auxiliary and support areas

Building type: . Laboratory-clean room

Configuration: $\quad$ Two laser bays, each $130.1 \mathrm{~m} \times 24.4 \mathrm{~m}$; capacitor areas $3,200 \mathrm{~m}^{2}$; support areas (described in Figs. 2-1, 2-2, 2-3)

Roof height: $\quad 15 \mathrm{~m}$

Construction type: . Pre-engineered sandwich, concrete/masonry or concrete Conveying system: 10-ton bridge crane 


\subsection{Laser and Target Area Building-Laser Bays (cont.)}

Special construction: - $3900 \mathrm{ks} / \mathrm{m}^{2}$ basemen : loor live load

- Temperature controlled to $20^{\circ} \mathrm{C} \pm .28^{\circ} \mathrm{C}$

- Vibration isolation to provide significant reduction of vibration of frequencies between 10 and $100 \mathrm{~Hz}$

- Grounding system to isolate electrical circuits for capacitors, computers, and diagnostics

Uniform building code occupancy classification: $\mathrm{B} 2 / \mathrm{H}^{*}$

Life safety code occupancy classification: Industrial

* Isolated areas 


\subsection{Laser and Target Area Building-Target Area}

Special construction:

- $3900 \mathrm{~kg} / \mathrm{m}^{2}$ basement floor live load

- $11450 \mathrm{~m}^{2}$ of target bay ( $33 \mathrm{~m}$ high)

- Temperature controlled to $20^{\circ} \mathrm{C} \pm .28^{\circ} \mathrm{C}$

- Vibration isolation to provide significant reduction of vibration of frequencies between 10 and $100 \mathrm{~Hz}$

- Grounding system to isolate electrical circuits for computers and diagnostics

Uniform building code occupancy classification: $\mathrm{B} 2 / \mathrm{H7}^{*}$

Life safety code occupancy classification: Industrial

* Isolated areas 


\subsection{Office Space}

Functional description: Office, storage, and meeting space for technical and administrative personnel

Building type: $\quad$ Commercial-office

Gross floor area: $\quad 7,432 \mathrm{~m}^{2}$

Roof height: As required for one or two-story building

Height per floor: $\quad 4.2 \mathrm{~m}$

Construction type: Steel, concrete and glass, two-story structure

Conveying systems: One passenger/service elevator

Mechanical:

Fire Protection Ordinary hazard, wet pipe sprinkler system

HVAC Zoned VAV

Electrical: $\quad$ Power req. $\quad 200 \mathrm{~kW}$

Lighting High intensity discharge fixtures-50 fc Emergency lighting, safety and security alarms on standby

Special construction: None

Uniform building code occupancy classification: B2 Life safety code occupancy classification: Business 


\subsection{Target Receiving and Inspection}

Functional description: Provide for the receiving and inspection of targets for NIF experiments

Building type: Laboratory

Gross floor area: $\quad 1,400 \mathrm{~m}^{2}$

Roof height: $\quad 6 \mathrm{~m}$

Height per floor: One-story

Construction type: Pre-engineered sandwich, concrete/masonry or concrete Conveying systems: $\quad$ N/A

Mechanical:

Electrical:

Power Req.

Lighting

Fire protection Ordinary hazard, wet pipe sprinkler system

HVAC Zoned VAV with temperature control. (See Special construction.) $200 \mathrm{~kW}$ High intensity discharge fixtures-70 fc Emergency lighting, safety and security alarms on standby

Special construction:

- Central chemical waste system

- High precision machine shop, requiring vibration isolation

- $280 \mathrm{~m}^{2}$ of Class 100 clean rooms

- $560 \mathrm{~m}^{2}$ of cryogenic laboratory space

- $975 \mathrm{~kg} / \mathrm{m}^{2}$ floor live load, minimum

- Temperature control for clean room, $20^{\circ} \mathrm{C} \pm .28^{\circ} \mathrm{C}$

Uniform building code occupancy classification: $\mathrm{B} 2 / \mathrm{H} 7^{*}$

Life safety code occupancy classification: Industrial

* Isolated areas 


\subsection{Assembly Area-Clean Room}

Functional description: Laboratory space to clean and assemble optical components, amplifiers, mirrors, optical switches, frequency convertors, final optics and pulse generators

Building type: Laboratory-clean room

Gross floor area: $\quad 1850 \mathrm{~m}^{2}$

Roof height:

$7.3 \mathrm{~m}$

Height per floor:

$4.3 \mathrm{~m}$ clear height

Construction type: Pre-engineered sandwich, concrete/masonry or concrete

Conveying system: $\quad 10$-tonne bridge crane

Mechanical:

$$
\begin{array}{ll}
\text { Plumbing } & \begin{array}{l}
\text { Compressed air, nitrogen below each at } \\
680 \mathrm{KPa}, \text { vacuum and cooling system } \\
(\mathrm{LCW})
\end{array} \\
\text { Fire protection } & \begin{array}{l}
\text { Ordinary hazard, wet pipe sprinkler } \\
\text { system } \\
\text { Zoned VAV with temperature control. } \\
\text { (See Special construction.) }
\end{array} \\
\text { Power req. } & \begin{array}{l}
500 \mathrm{~kW} ; 277 / 480 \mathrm{~V} \text { and } 120 / 208 \mathrm{~V} \text { power } \\
\text { distribution for laboratories } \\
\text { High intensity discharge fixtures-70 fc } \\
\text { Emergency lighting, safety and security } \\
\text { alarms on standby }
\end{array}
\end{array}
$$

Electrical:

Special construction:

- $1200 \mathrm{~kg} / \mathrm{m}^{2}$ floor live load, minimum

- $1000 \mathrm{~m}^{2}$ clean rooms $(60 \%$ Class 100 and $40 \%$ Class 1000)

- $4.3 \mathrm{~m}$ high clean room ceiling (to bottom of HEPA filters)

- $12 \mathrm{~m}$ wide clean room

- Temperature control for clean rooms, $20^{\circ} \mathrm{C} \pm .28^{\circ} \mathrm{C}$

Uniform building code occupancy classification: B2

Life safety code occupancy classification: Industrial 


\subsection{Assembly Area-General}

Functional description: Assembly of mechanical and electrical components not requiring a clean room environment

Building type: Industrial

Gross floor area: $\quad 9100 \mathrm{~m}^{2}$

Roof height: $\quad 9 \mathrm{~m}$

Height per floor: One-story, $5.5 \mathrm{~m}$ clear hook height for crane

Construction type: Pre-engineered sandwich, concrete/masonry or concrete

Conveying system: 10-tonne bridge crane

Mechanical:

$\begin{array}{ll}\text { Plumbing } & \begin{array}{l}\text { Compressed air, nitrogen, helium, arg } \\ \text { gases, vacuum and cooling water (LCW) }\end{array} \\ \text { Fire protection } & \begin{array}{l}\text { Ordinary hazard, wet pipe sprinkler } \\ \text { system }\end{array} \\ \text { HVAC } & \begin{array}{l}\text { Zoned VAV with fume hood exhaust } \\ \text { (welding) }\end{array}\end{array}$

Electrical:

Power req. $\quad 200 \mathrm{~kW} ; 277 / 480 \mathrm{~V}$ and $120 / 208 \mathrm{~V}$ power Lighting High intensity discharge fixtures-70 fc Emergency lighting, safety and security alarms on standby

Special construction: - 10-t hydraulic dock levers

- $1950 \mathrm{~kg} / \mathrm{m}^{2}$ floor live load, minimum

- $30 \mathrm{~m}$ building width, minimum

Uniform building code occupancy classification: B2 Life safety code occupancy classification: Industrial 


\subsection{Optics Maintenance and Refurbishing Area}

Functional description: Laser, optics support, optical testing coating and metrology

Building type:

Laboratory

Gross floor area:

$3700 \mathrm{~m}^{2}$

Height per floor:

One-story

Construction type:

Pre-engineered sandwich, concrete/masonry or concrete

Mechanical:

Plumbing Compressed air, nitrogen, helium at 680 $\mathrm{KPa}$, vacuum and cooling water (LCW)

Fire protection Ordinary hazard, wet pipe sprinkler system

HVAC Zoned VAV with temperature control

Electrical:

Power req. $\quad 300 \mathrm{~kW}, 277 / 480 \mathrm{~V}$ and $120 / 208 \mathrm{~V}$ power distribution to laboratories.

Lighting High intensity discharge fixtures-70 fc Emergency lighting, safety and security alarms on standby

Special construction: - Vibration isolation, 10 to $100 \mathrm{~Hz}$

- $1200 \mathrm{~kg} / \mathrm{m}^{2}$ floor live load, minimum

- $325 \mathrm{~m}^{2}$ Class 100 clean rooms

- Temperature specifications for clean rooms, $20^{\circ} \mathrm{C} \pm .28^{\circ} \mathrm{C}$

Uniform building code occupancy classification: B2

Life safety code occupancy classification: Industrial 


\subsection{Optics Storage}

Functional description: Provide a temperature and humidity controlled environment to store high value optics and crystals for use as spare and replacement parts during operation and inventory during construction of NIF

Building type: Storage-warehouse

Gross floor area: $2000 \mathrm{~m}^{2}$

Roof height:

$7.3 \mathrm{~m}$

Height per floor:

One-story

Construction type:

Pre-engineered sandwich, concrete/masonry or concrete

Mechanical:

Fire protection Ordinary hazard, wet pipe sprinkler system

HVAC Zoned VAV with temperature and humidity control

Electrical:

Power req. $100 \mathrm{~kW}$

Lighting Fixtures to maintain-30 fc Emergency lighting, safety and security alarms on standby

Special construction:

- $975 \mathrm{~kg} / \mathrm{m}^{2}$ floor live load, minimum

- Temperature control for crystal storage, $20^{\circ} \mathrm{C} \pm 28^{\circ} \mathrm{C}$

- Humidity control for crystal storage, $<30 \%$

Uniform building code occupancy classification: B2 Life safety code occupancy classification: Industrial 


\subsection{Warehouse}

Functional description: Bulk storage of materials, equipment, and supplies

Building type:

Roof height:

Construction type:

Mechanical:
Gross floor area:

Industrial-warehouse

$2800 \mathrm{~m}^{2}$

$6 \mathrm{~m}$

Pre-engineered metal building

Fire protection

Ordinary hazard, wet pipe sprinkler system

HVAC System required for personnel comfort

Electrical:

Uniform building code occupancy classification: B2 Life safety code occupancy classification: Storage 


\subsection{Electrical and Mechanical Shops}

Functional description: Provide program support with fabrication and maintenance of mechanical and electrical components

Building type: Electrical/Mechanical Maintenance

Gross floor area: $\quad 1100 \mathrm{~m}^{2}$

Roof height: $\quad 6 \mathrm{~m}$

Height per floor: One-story

Construction type: Pre-engineered sandwich, concrete/masonry or concrete Conveying system: 7-tonne bridge crane

Mechanical:

Plumbing Compressed air at $680 \mathrm{KPa}$, cooling water (LCW)

Fire protection Ordinary hazard, wet pipe sprinkler system

HVAC Zoned VAV with fume hood exhaust

Electrical:

Power req. $\quad 200 \mathrm{~kW} ; 277 / 480 \mathrm{~V}$ and $120 / 208 \mathrm{~V}$ power Lighting High intensity discharge fixtures-70 fc Emergency lighting, safety and security alarms on standby

Special construction: $\quad 1750 \mathrm{~kg} / \mathrm{m}^{2}$ floor live load, minimum

Uniform building code occupancy classification: B2 Life safety code occupancy classification: Industrial 


\subsection{Others}

\subsubsection{Shipping Receiving, and Central Stores}

Functional description: Receiving, storage, distribution and shipment of materials, equipment and supplies

Building type: Industrial-Factory/Warehouse

Gross floor area: $\quad 1300 \mathrm{~m}^{2}$

Roof height: $\quad 6 \mathrm{~m}$

Height per floor: One story

Construction type: Pre-engineered metal building

Mechanical:

Fire protection Ordinary hazard, wet pipe sprinkler system

HVAC Systems required for personnel comfort

Electrical:
Power req.
$100 \mathrm{~kW}$
Lighting High intensity discharge fixtures-70 fc Emergency lighting, safety and security alarms on standby

Special construction: Four 10-t hydraulic dock levers

Uniform building code occupancy classification: B2

Life safety code occupancy classification: Industrial 


\subsubsection{Medical Building}

Functional description: Medical office, dispensary, examination, and therapy

Building type:

Gross floor area:

Roof height:

Height per floor:

Construction type:

Mechanical:
Commercial-medical office/clinic $700 \mathrm{~m}^{2}$

$5 \mathrm{~m}$

One story

Pre-engineered sandwich, concrete/masonry or concrete

Plumbing

Standard service fixtures, supply and drainage

Fire protection Ordinary hazard, wet pipe sprinkler system

HVAC Systems required for personnel comfort

Electrical:

Power req.

Lighting
$100 \mathrm{~kW}$ High intensity discharge fixtures, $70 \mathrm{fc}$ Emergency lighting, safety and security alarms on standby

Special construction: None

Uniform building code occupancy classification: B2

Life safety code occupancy classification: Business 


\subsubsection{Cafeteria}

Functional description: 250-seat cafeteria

Building type:

Gross floor area:

Roof height:

Height per floor:

Construction type:

Mechanical:
Commercial-cafeteria

$750 \mathrm{~m}^{2}$

$6 \mathrm{~m}$

One story

Pre-engineered sandwich, concrete/masonry or concrete

Plumbing

Standard service fixtures, supply and drainage

Fire protection Ordinary hazard, wet pipe sprinkler system

HVAC Systems required for personnel comfort

Electrical:

$\begin{array}{ll}\text { Power req. } & 100 \mathrm{~kW} \\ \text { Lighting } & \text { High intensity discharge fixtures, } 70 \mathrm{fc} \\ & \begin{array}{l}\text { Emergency lighting, safety and security } \\ \text { alarms on standby }\end{array}\end{array}$

Special construction: None

Uniform building code occupancy classification: A3

Life safety code occupancy classification: Assembly 


\subsubsection{Garage and Gas Station}

Functional description: Routine light maintenance, repair, refueling, and cleaning of plant vehicles and heavy equipment

Building type: Industrial-garage

- Gross floor area: $\quad 465 \mathrm{~m}^{2}$

Roof height. $\quad 7.3 \mathrm{~m}$

Height per floor: $\quad 7.3 \mathrm{~m}$

Construction type: Pre-engineered metal building

Conveying system: Hydraulic lifts

Mechanical:

$\begin{array}{ll}\text { Plumbing } & \begin{array}{l}\text { Standard service fixtures, supply and } \\ \text { drainage }\end{array} \\ \text { Fire protection } & \begin{array}{l}\text { Ordinary hazard, wet pipe sprinkler } \\ \text { system }\end{array} \\ \text { HVAC } & \text { Systems requred for personnel comfort }\end{array}$

Electrical:

$\begin{array}{ll}\text { Power req. } & 100 \mathrm{~kW} \\ \text { Lighting } & \text { High intensity discharge fixtures, } 70 \mathrm{fc} \\ & \begin{array}{l}\text { Emergency lighting, safety and security } \\ \text { alarms on standby }\end{array}\end{array}$

Special construction: None

Uniform building code occupancy classification: $\mathrm{H} 4$

Life safety code occupancy classification: Industrial 


\subsubsection{Fire Station}

Functional description: House fire and emergency equipment, emergency communications, living quarters for personnel and training facilities

Building type: Industrial

Gross floor area: $\quad 5700 \mathrm{~m}^{2}$

Roof height: $\quad 12 \mathrm{~m}$

Height per floor: one- or two-story

Construction type: Pre-engineered sandwich or concrete

Conveying system: Passenger/service elevator

Mechanical:

$\begin{array}{ll}\text { Plumbing } & \begin{array}{l}\text { Standard service fixtures, supply and } \\ \text { drainage }\end{array} \\ \text { Fire protection } & \begin{array}{l}\text { Ordinary hazard, wet pipe sprinkler } \\ \text { system }\end{array} \\ \text { HVAC } & \text { Systems required for personnel comfort }\end{array}$

Electrical:

$\begin{array}{ll}\text { Power req. } & 200 \mathrm{~kW} \\ \text { Lighting } & \text { High intensity discharge fixtures, } 70 \mathrm{fc} \\ & \begin{array}{l}\text { Emergency lighting, safety and security } \\ \text { alarms on standby }\end{array}\end{array}$

Special construction: None

Uniform building code occupancy classification: B2

Life safety code occupancy classification: Industrial/residential 


\subsubsection{Security and Badging}

Functional description: Provide for the NIF site security and badging of personnel

Building type:

Gross floor area:

Roof height:

Height per floor:

Construction type:

Mechanical:
Commercial一office

$110 \mathrm{~m}^{2}$

$4.3 \mathrm{~m}$

one-story

Steel, concrete, and glass

Plumbing Standard service fixtures, supply and drainage

Fire protection Ordinary hazard, wet pipe sprinkler system

HVAC

Systems required for personnel comfort

Electrical:

Power req.

$200 \mathrm{~kW}$

Lighting

High intensity discharge fixtures, $70 \mathrm{fc}$

Emergency lighting, safety and security alarms on standby

Special construction: None

Uniform building code occupancy classification: B2

Life safety code occupancy classification: Business 


\section{Appendix A}

\section{Personnel Qualifications for the Engineering and Technical Support for NIF Operations}




\section{NIF Mechanical Engineering, Operations, and Maintenance Support:}

Lead Engineer - very experienced in several areas of mechanical engineering (project management, high-power glass laser system design, structural design, etc.) and capable of directing junior engineers.

Engineer - qualified in a specific area such as precision mechanisms, optical design, or vacuum; or someone of a junior level.

Lead Designer - person with many years experience designing laser related hardware and directing a design group.

Designer - past experience in supporting a design group making a variety of CAD drawings for laser systems or other high-tech industries.

Coordinator - experienced at purchasing custom fabrications of large size, high precision, or vacuum construction; or off-the-shelf components.

Technician Supervisor - experienced in precision assembly, optical processing, or operations and capable of directing a technician support group.

Coatings/Measurements Technician - experienced in optical cleaning and coating, interferometric and photometric measurements, and optical assembly.

Clean Room Assembly Technician - experienced in assembling large, complex, and delicate optomechanical components in a clean room environment.

Contamination Control Technician - capable of cleaning and maintaining a variety of clean rooms throughout NIF, from Class 100 to Class 10,000.

Machinist - experienced in a variety of crafts such as mills, lathes, or welding.

Laser Bay Technician - capable of assembling, maintaining, or operating components in the laser bay, such as amplifiers, spatial filters, or Pockels cells.

Target Bay Technician - capable of assembling, maintaining, or operating components in the target bay, such as turning mirrors, target inserter, or vacuum system.

Switchyard Technician - capable of assembling, maintaining, or operating components in the switchyard, such as turning mirrors, support frames, or laser diagnostics. 
General Installation - capable of assembling or maintaining other NIF support areas such as side laboratories or building equipment.

Diagnostic Support Technician - experienced at developing, assembling, or maintaining a variety of laser fusion diagnostics such as picosecond gated detectors, neutron scintillator diagnostics, or optical spectrometer instruments.

Diagnostic Coordinator - capable of coordinating target experiment needs with diagnostic capabilities and other system limitations.

Target Handler - experienced at precision, miniature component inspection and handling using microscopes and other specialized instruments.

\section{NIE Electrical Engineering, Operations, and Maintenance Support:}

Building Manager - very experienced in the installation, activation, operation and maintenance of large high-power glass laser systems, and capable of interacting with a variety of disciplines.

Lead Engineer - very experienced in several areas of electrical engineering and capable of directing junior engineers.

Engineer - qualified in a specific area such as pulsed power, or highbandwidth diagnostics; or someone of a junior level

Safety Officer - experienced in laser, radiation, industrial, fire, chemical and other areas of hazards control, and capable of directing building safety technicians.

Computer Scientists - experienced computer scientists capable of supporting target designers and maintaining encrypted links with major off-site super computing environments, as well as debugging both software and hardware.

Lead Designer - person with many years experience in designing complex electronics circuits and integrated systems and directing a design group.

Designer - past experience in supporting a design group making a variety of $\mathrm{CAD}$ drawings of electronics circuits and systems or other high-tech industries.

Coordinator - experienced at purchasing electronics components or systems, and designing electrical installations.

Technician Supervisor - experienced in electronics technology or laser electro- 
optics technology, and capable of directing a technician support group.

Diagnostic Development Technician - experience in high-bandwidth electronic design, testing, and troubleshooting.

Power Conditioning Technician - experienced in high voltage $(20-\mathrm{kV})$ pulsedpower circuits.

System Alignment Technician - Laser Electro-Optics Technician experienced in handling, aligning and operating large complex lasers and electro-optical devices.

Laser Diagnostic Technician - Laser Electro-Optics Technician experienced in lasers operations and beam diagnostics.

Front End Technician - Laser Electro-Optics Technician experienced in handling, aligning and operating lasers and electro-optical devices.

Target Diagnostic Technician - Electronics technician experienced in operating and maintaining electronics systems used for high-bandwidth measurements

Technical Photography Technician - Photographic technician experienced in scientific data processing and handling.

Controls Technician - Electronics Technician experienced in installation, trouble shooting, and maintenance of complex integrated control systems.

General Installation Technician - Entry level electronics technicians capable of assembly and installation of general electronics equipment, including cable installation and termination and simple chassis assembly.

Safety Technician - Industrial health and safety technician experienced in supporting a diverse environment involving high voltage, lasers, chemical, fall, oxygen deficiency, and radiological hazards among others.

Data Processing Technician - Experienced in digitizing film data and running computer programs to process experimental data.

EE Shops Technician - Electronics technician capable of fabricating and assembly of complex circuits and chassis.

Optics Inventory Technicians - Technician experienced in optics handling, acceptance testing and inventory maintenance. 


\section{Appendix B}

\section{Personnel Qualifications for the Scientific Staff for NIF Technical Operations}


Scientific Director - Ph.D. or equivalent experience in physics, material science or engineering and many years of experience in guiding an experimental program, and conducting experiments at a large building.

Lab Liaison - Ph.D. or equivalent experience in experimental plasma physics or nuclear physics and several years of experience in designing and performing experiments at large ICF facilities. These individuals will represent their respective laboratories in setting priorities and schedules for the building.

Shot Physicist - Ph.D. or equivalent experience in experimental plasma physics or nuclear physics and several years of experience in designing and performing experiments at large ICF facilities.

Laser Scientific Manager - Ph.D. or equivalent experience in applied physics, electrical engineering or material science with many years of experience in designing, activating, and operating large high-power, solid-state lasers plus experience in managing a large diverse team of scientists.

Laser System Scientist - Ph.D. or equivalent experience in applied physics, electrical engineering or material science. These are experimentalists with several years of experience with high power solid-state lasers who understand issues associated with laser system gain, transmission, beam profile, saturation characteristics, pointing precision, etc.

Laser System Analyst - Ph.D. or equivalent experience in applied physics, electrical engineering or material science. These are scientists with many years of experience developing and validating physics models of phenomena associated with high power solid-state lasers such as laser system gain, transmission, beam profile, saturation characteristics, pointing precision, pulse shaping, etc.

Plasma Physicist - Ph.D. or equivalent experience in plasma physics or computational physics and several years of experience in interpreting hohlraum results and suggesting ways to reduce instabilities.

Capsule Designer - Ph.D. or equivalent experience in plasma physics, astrophysics, mathematics or computational physics and several years of experience in ICF capsule design and modeling.

Hohlraum Designer - Ph.D. or equivalent experience in plasma physics, astrophysics, mathematics or computational physics and several years of experience in hohlraum design and modeling.

Cryogenic Scientist - Ph.D. or equivalent experience in physics, material 
science or engineering and several years of experience in resolving issues in the design of cryogenic systems and ICF cryogenic targets.

Material Scientist - Ph.D. or equivalent experience in material science or engineering and several years of experience in resolving issues in the design and fabrication of ICF targets.

Laser Diagnostic Scientist - Ph.D. or equivalent experience in applied physics, electrical engineering or material science with several years of experience in developing, calibrating, and operating complex laser diagnostics on large high-power, solid-state lasers.

Optical Damage Scientist - Ph.D. or equivalent experience in material science, or applied physics with several years of experience in studying and solving problems associated with damage to optical components and coatings in large high-power, solid-state lasers.

Oscillator and Preamplifier Scientist - Ph.D. or equivalent experience in applied physics, electrical engineering or material science with several years of experience in developing, characterizing, and operating oscillators and pulseshaping systems on large high-power, solid-state lasers.

X-ray Diagnostician - Ph.D. or equivalent experience in experimental plasma physics or nuclear physics and several years of experience in designing, activating, calibrating and operating $x$-ray diagnostics at large ICF facilities.

Optical Diagnostician - Ph.D. or equivalent experience in experimental plasma physics or nuclear physics and several years of experience in designing, activating, calibrating and operating optical diagnostics at large ICF facilities.

Neutron Diagnostician - Ph.D. or equivalent experience in nuclear physics or experimental plasma physics and several years of experience in designing, activating, calibrating and operating neutron diagnostics at large ICF facilities.

Fast-Timing Scientist - Ph.D. or equivalent experience in experimental plasma physics or nuclear physics and several years of experience in designing, activating, calibrating and operating high-speed diagnostics at large ICF facilities.

Nonlinear Optical Scientist - Ph.D. or equivalent experience in applied optics, applied physics, electrical engineering or material science. These are experimentalists with several years of experience with nonlinear optics who understand issues associated with frequency conversion performance, selffocusing, transverse parasitic processes, Raman scattering, etc. 
Nonlinear Optics Analyst - Ph.D. or equivalent experience in applied physics, electrical engineering or material science. These are scientists with several years of experience developing and validating physics models of nonlinear optical phenomena such as frequency conversion performance, self-focusing, transverse parasitic processes, Raman scattering, etc. 


\section{Appendix C}

\section{Construction Impacts of NIF Buildings and Specific Host Sites}




\section{C-1 Construction impacts}

Construction impacts are site-dependent and based on what infrastructure exists at that site and what existing structures, if any, are proposed for the NIF. Each site will have a unique estimate of construction manpower, resource utilization (e.g., yards of concrete, forms, conduit, etc.), construction utilities, construction emissions, noise levels, disruption of other activities, etc. Data on waste generated by removal of existing structures will also be unique to each proposed site. An example of construction impacts is provided for illustration purposes only. Each host site shall provide the data required for their specific conditions.

C-1.1 Land Area Requirements: (example)

Example estimates of the land area impacts associated with major new construction of the NIF complex are presented. These estimates identify floor space, roads, parking, and construction laydown requirements.

Table C-1. Additional Space for New Buildings

\begin{tabular}{|c|c|c|c|}
\hline $\begin{array}{c}\text { Floor Space } \\
\left(\mathrm{m}^{2}\right)\end{array}$ & $\begin{array}{c}\text { Roads } \\
\left(\mathrm{ms}^{2}\right)\end{array}$ & $\begin{array}{c}\text { Parking } \\
\left(\mathrm{m}^{2}\right)\end{array}$ & $\begin{array}{c}\text { Construction } \\
\text { Laydown }\left(\mathrm{m}^{2}\right)\end{array}$ \\
\hline \hline 44,000 & 370,000 & 200,000 & 16,350 \\
\hline
\end{tabular}

\section{C-1.2 Construction Material/Resource Needs: (example)}

Provide estimates of utilities: water and electricity, solids: concrete, steel, liquid fuels and gases to be consumed during construction.

Table C-2. Construction Materials and other Resources

\begin{tabular}{|c|c|c|c|c|c|}
\hline $\begin{array}{c}\text { Water } \\
(1 / \mathrm{d})\end{array}$ & $\begin{array}{c}\text { Electricity } \\
(\mathrm{kWh})\end{array}$ & $\begin{array}{c}\text { Concrete } \\
\left(\mathrm{m}^{3}\right)\end{array}$ & $\begin{array}{c}\text { Steel } \\
(\text { tonnes })\end{array}$ & $\begin{array}{c}\text { Liquid } \\
\text { Fuels } \\
(\mathrm{l})\end{array}$ & $\begin{array}{c}\text { Gases } \\
\left(\mathrm{m}^{3}\right)\end{array}$ \\
\hline \hline 11,400 & $24 \mathrm{mWh}$ & 60,000 & 10,000 & $1,500,000$ & 9,000 \\
\hline
\end{tabular}

$\mathrm{kWh}=$ kilowatt hours (total construction period) 


\section{C-1.3 Construction Wastes, Effluent, and Emissions (example)}

Provide estimates of volumes of construction wastes generated and air emissions associated with construction.

Table C-3. Wastes Generated during Construction $\left(\mathrm{m}^{3}\right)$

\begin{tabular}{|c|c|c|c|c|c|c|c|c|c|c|c|}
\hline \multicolumn{2}{|c|}{ Transuranic } & \multicolumn{2}{|c|}{ Low-level } & \multicolumn{2}{c|}{ Hazardous } & \multicolumn{2}{c|}{$\begin{array}{c}\text { Mixed Low- } \\
\text { level }\end{array}$} & \multicolumn{2}{c|}{$\begin{array}{c}\text { Nonhazardous } \\
\text { (Sanitary) }\end{array}$} & \multicolumn{2}{c|}{$\begin{array}{c}\text { Other } \\
\text { Nonhazardous }\end{array}$} \\
\hline \hline Liquid & Solid & Liquid & Solid & Liquid & Solid & Liquid & Solid & Liquid & Solid & Liquid & Solid \\
\hline None & None & None & None & None & None* & None & None & 11,000 & 500 & 1,000 & 1000 \\
\hline
\end{tabular}

* assumes no contaminated soil or structures to be removed

Table C-4. Air Emissions for the Construction of Project Buildings

\begin{tabular}{|c|c|}
\hline $\begin{array}{c}\text { Criteria Pollutants } \\
\text { Particulates }\end{array}$ & $\begin{array}{c}\text { Emission Rate (kg/yr) } \\
\text { Completely site dependent }\end{array}$ \\
\hline *CO & 135 \\
\hline${ }^{*}$ NOx & 35 \\
\hline * SOx & 35 \\
\hline * Volatile organic compound & 32 \\
\hline * Particulate & 32 \\
\hline $\begin{array}{c}\text { Hazardous Air Pollutants and Other } \\
\text { Toxic Compounds }\end{array}$ & Emission Rate (kg/yr) \\
\hline \hline None & None \\
\hline * Construction equipment and vehicle exhausts \\
\hline
\end{tabular}

Emission rates are based upon average construction year.

C-1.4 Construction Employment: (example)

A typical profile of estimated peak project construction employment (construction forces only). 
Table C-5. Average Full-Time Construction Employment

\begin{tabular}{|l|l|}
\hline Year & Construction Workers \\
\hline 1996 & \\
\hline 1997 & 150 \\
\hline 1998 & 200 \\
\hline 1999 & 100 \\
\hline 2000 & 100 \\
\hline 2001 & \\
\hline 2002 & \\
\hline 2003 & \\
\hline 2004 & \\
\hline 2005 & \\
\hline
\end{tabular}

